\title{
Intramolecular Diels-Alder Reactions in Ruthenium Vinylidene Complexes Containing Anthracenyl Groups
}

\author{
Shu-Hao Chang, Wen-Ru Tsai, Hao-Wei Ma, Ying-Chih Lin,* Shou-Ling Huang, \\ Yi-Hung Liu, and Yu Wang \\ Department of Chemistry, National Taiwan University, Taipei, Taiwan 106, Republic of China
}

Received November 26, 2008

\begin{abstract}
An intramolecular Diels-Alder (IMDA) reaction was observed at room temperature between an allyl group and a chloroanthracenyl group that were both bonded to the vinylidene ligand of the cationic ruthenium complex $\left.[\mathrm{Ru}]=\mathrm{C}=\mathrm{C}\left(\mathrm{CH}_{2} \mathrm{CH}=\mathrm{CH}_{2}\right) \mathrm{CH}\left(\mathrm{CH}_{2} \mathrm{CH}=\mathrm{CH}_{2}\right)\left(\mathrm{C}_{14} \mathrm{H}_{8} \mathrm{Cl}\right)^{+}(\mathbf{6} ; \mathrm{Ru}]=\mathrm{Cp}\left(\mathrm{PPh}_{3}\right)_{3} \mathrm{Ru}\right)$. The vinylidene ligand functions as a mediator to bring the allyl and the chloroanthracenyl groups in proximity for the reaction to take place. For the two allyl groups in $\mathbf{6}$, only the one at $\mathrm{C}_{\beta}$ underwent the reaction. In the analogous triethylphosphine complex $\mathbf{6}^{\prime}$, more electron-donating triethylphosphine ligands lower the rate of the IMDA reaction. For this IMDA reaction in several vinylidene complexes, each with a nonchlorinated anthracenyl ligand, the rate of the reaction is accelerated by the presence of an unsaturated functional group at $\mathrm{C}_{\gamma}$ of the vinylidene ligand, particularly by a terminal alkynyl substituent. The solidstate structures of two IMDA reaction products have been determined by single-crystal X-ray diffraction analysis.
\end{abstract}

\section{Introduction}

As catalytic enyne chemistry has become the focus of many recent explorations, ${ }^{1,2}$ an understanding of the chemical reactivity of vinylidene complexes containing additional olefinic functionalities may disclose fundamental key steps in the reactions of enynes. ${ }^{3}$ Considering that the vinylidene moiety originates from a terminal alkynyl functionality, ${ }^{4}$ the entire vinylidene ligand with an additional olefin group is perceived as an enyne. We previously reported a novel metathesis of two $\mathrm{C}=\mathrm{C}$ double bonds in vinylidene complexes tethered with a vinyl terminus. ${ }^{3}$ This metathesis process is observed in several systems with 1,5-enyne. As the synthesis of vinylidene moieties could be readily achieved by electrophilic addition of organic halides to metal acetylide complexes, we aimed to study the reaction of the vinylidene complex with an anthracenyl group and a proximal vinyl group. Here we report the reactions of several vinylidene complexes containing anthracenyl or chlo-

* To whom correspondence should be addressed. E-mail: yclin@ ntu.edu.tw.

(1) (a) Driver, S. T.; Geissert, A. J. Chem. Rev. 2004, 104, 1317-1382. (b) Nevado, C.; Cárdenas, D. J.; Echavarren, A. M. Chem. Eur. J. 2003, 9 , 2627-2635. (c) Méndez, M.; Mamane, V.; Fürstner, A. Chemtracts: Org. Chem. 2003, 16, 397-425.

(2) (a) Mamane, V.; Gress, T.; Krause, H.; Fürstner, A. J. Am. Chem. Soc. 2004, 126, 8654-8655. (b) Harrak, Y.; Blaszykowski, C.; Bernard, M.; Cariou, K.; Mainetti, E.; Mouries, V.; Dhimane, A. L.; Fensterbank, L.; Malacria, M. J. Am. Chem. Soc. 2004, 126, 8656-8657. (c) Luzung, M. R.; Markham, J. P.; Toste, F. D. J. Am. Chem. Soc. 2004, 126, 10858 10859. (d) Nieto-Oberhuber, C.; Muñoz, M. P.; Buñuel, E.; Nevado, C.; Cárdenas, D. J.; Echavarren, A. M. Angew. Chem., Int. Ed. 2004, 43, 2402 2406.

(3) (a) Cheng, C. W.; Kuo, Y. C.; Chang, S. H.; Lin, Y. C.; Liu, Y. H.; Wang, Y. J. Am. Chem. Soc. 2007, 129, 14974-14980. (b) Yen, Y. S.; Lin, Y. C.; Huang, S. L.; Liu, Y. H.; Sung, H. L.; Wang, Y. J. Am. Chem. Soc. 2005, 127, 18037-18045.

(4) (a) de los Ríos, I.; Tenorio, M. J.; Puerta, M. C.; Valerga, P. J. Am. Chem. Soc. 1997, 119, 6529-6538. (b) Tenorio, M. J.; Puerta, M. C.; Valerga, P. Organometallics 1997, 16, 5528-5535. (c) Wakatsuki, Y.; Koga, N.; Yamazaki, H.; Morokuma, K. J. Am. Chem. Soc. 1994, 116, 81058111. (d) Touchard, D.; Haquette, P.; Pirio, N.; Toupet, L.; Dixneuf, P. H. Organometallics 1993, 12, 3132-3139. (e) Silvestre, J.; Hoffmann, R. Helv. Chim. Acta 1985, 68, 1461-1506. roanthracenyl groups and vinyl groups bonded to the ligand. The intramolecular Diels-Alder (IMDA) reaction ${ }^{5-7}$ takes place under relatively mild conditions, yielding vinylidene complexes with polycyclic ligands.

\section{Results and Discussion}

Intramolecular Diels-Alder Reaction in a Vinylidene Complex with $\mathbf{P P h}_{3}$. A facile IMDA reaction was observed at room temperature in the cationic ruthenium bis(triphenylphosphine) vinylidene complex $[\mathrm{Ru}]=\mathrm{C}=\mathrm{C}\left(\mathrm{CH}_{2} \mathrm{CH}=\mathrm{CH}_{2}\right) \mathrm{CH}$ $\left(\mathrm{CH}_{2} \mathrm{CH}=\mathrm{CH}_{2}\right)\left(\mathrm{C}_{14} \mathrm{H}_{8} \mathrm{Cl}\right)^{+}\left(\mathbf{6} ;[\mathrm{Ru}]=\mathrm{Cp}\left(\mathrm{PPh}_{3}\right)_{3} \mathrm{Ru}\right)$, with a 10chloroanthracenyl group and a terminal vinyl group each joining to the vinylidene ligand at $\mathrm{C}_{\gamma}$ and $\mathrm{C}_{\beta}$, respectively (see Scheme 1). For 6 the two allyl groups were consecutively added to the ligand by nucleophilic and electrophilic addition reactions. The synthesis and characterization of these complexes shown in Scheme 1 are described below.

Compound 2, a substituted propargyl alcohol, was first synthesized from the reaction of $\mathbf{1}$ with $\mathrm{HC} \equiv \mathrm{CMgBr}$ according to the literature method. ${ }^{8}$ The allenylidene complex $\mathbf{4}$ with a 10-chloroanthracenyl group bonded at $\mathrm{C}_{\gamma}$ as a deep blue powder was then prepared in high yield from the reaction of $\mathbf{2}$ with $[\mathrm{Ru}] \mathrm{Cl}\left(\mathbf{3} ;[\mathrm{Ru}]=\mathrm{Cp}\left(\mathrm{PPh}_{3}\right)_{2} \mathrm{Ru}\right)^{9}$ in the presence of $\mathrm{KPF}_{6}$ in $\mathrm{CH}_{2} \mathrm{Cl}_{2}{ }^{10}{ }^{10}$ Analytical data of complex 4 support the proposed

(5) (a) Richter, F.; Bauer, M.; Perez, C.; Maichle-Mössmer, C.; Maier, M. E. J. Org. Chem. 2002, 67, 2474-2480. (b) Tantillo, D. J.; Houk, K. N.; Jung, M. E. J. Org. Chem. 2001, 66, 1938-1940.

(6) (a) Iafe, R. G.; Houk, K. N. J. Org. Chem. 2008, 73, 2679-2686. (b) Larsen, S. D.; Grieco, P. A. J. Am. Chem. Soc. 1985, 107, 1768-1769. (7) Ciganek, E. J. Org. Chem. 1980, 45, 1497-1505.

(8) Akiyama, S.; Nakagawa, M. Bull. Chem. Soc. Jpn. 1970, 43, 35613566.

(9) Bruce, M. I.; Hameister, C.; Swincer, A. G.; Wallis, R.; Ittel, S. D. Inorg. Synth. 1990, 28, 270-272.

(10) (a) Werner, H. Chem. Commun. 1997, 903-904. (b) Touchard, D.; Dixneuf, P. H. Coord. Chem. Rev. 1998, 178-180, 409-429. (c) Bruce, M. I. Chem. Rev. 1998, 98, 2797-2858. (d) Bianchini, C.; Mantovani, N.; Marchi, A.; Marvelli, L.; Masi, D.; Peruzzini, M.; Rossi, R.; Romerosa, A. Organometallics 1999, 18, 4501-4508. 
Scheme 1

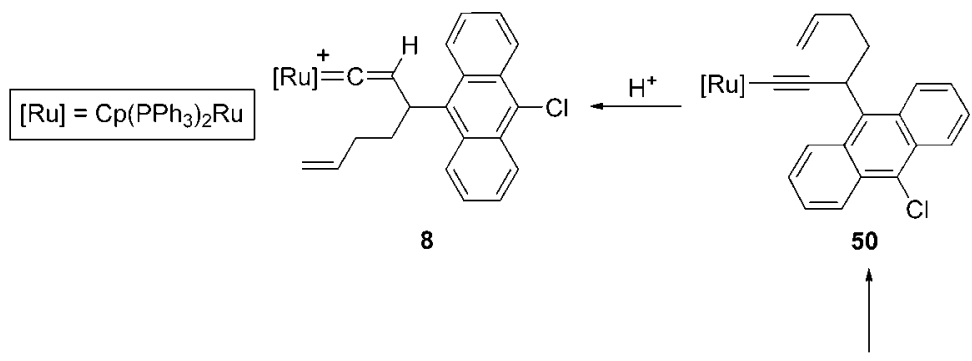

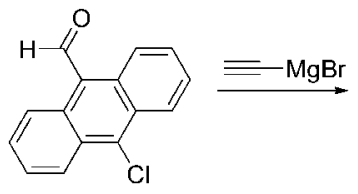

1

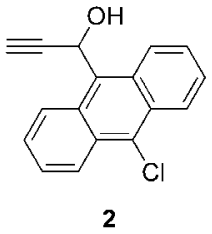

2

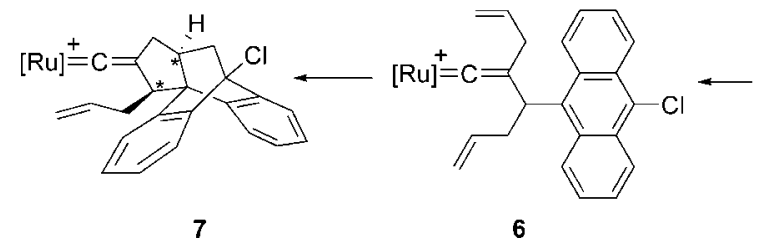

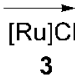

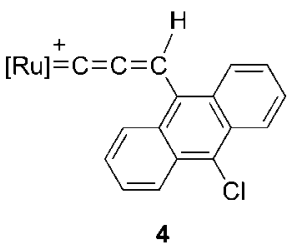

$\mathrm{CH}_{2} \mathrm{CHCH}_{2} \mathrm{MgBr}$

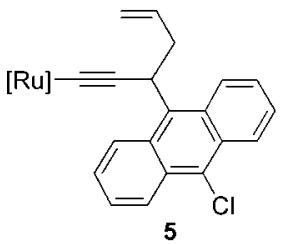

formula. Also, spectroscopic data are characteristic for the allenylidene ligand. For example, the ${ }^{1} \mathrm{H}$ NMR spectrum of 4 exhibits one downfield singlet resonance at $\delta 10.52$ assigned to the hydrogen at $\mathrm{C}_{\gamma}$ of the allenylidene ligand. The triplet resonance at $\delta 300.9$ with ${ }^{2} J_{\mathrm{PC}}=17.5 \mathrm{~Hz}$ in the ${ }^{13} \mathrm{C} \mathrm{NMR}$ spectrum of 4 is assigned to $\mathrm{C}_{\alpha}{ }^{11}{ }^{11}$ The ${ }^{31} \mathrm{P}$ NMR spectrum shows one singlet resonance at $\delta 46.34$.

Treatment of $\mathbf{4}$ with $\mathrm{CH}_{2}=\mathrm{CHCH}_{2} \mathrm{MgBr}$ caused the allylation to take place at $\mathrm{C}_{\gamma}$, yielding the neutral acetylide complex $\mathbf{5}$, which has been characterized by analytical and spectroscopic methods. The ${ }^{13} \mathrm{C}$ NMR spectrum of $\mathbf{5}$ showing a triplet resonance at $\delta 97.2$ with ${ }^{2} J_{\mathrm{PC}}=25.3 \mathrm{~Hz}$ assigned to $\mathrm{C}_{\alpha}$ is consistent with the presence of the acetylide ligand. The ${ }^{31} \mathrm{P}$ NMR spectrum displays two doublet resonances at $\delta 51.60$ and 50.70 with ${ }^{2} J_{\mathrm{PP}}=37.2 \mathrm{~Hz}$ due to the presence of a stereogenic carbon center on the acetylide ligand.

Then the electrophilic allylation reaction of $\mathbf{5}$, already with an allyl group at $\mathrm{C}_{\gamma}$ of the acetylide ligand, with allyl iodide takes place at $\mathrm{C}_{\beta}$ in $\mathrm{CH}_{2} \mathrm{Cl}_{2}$ at room temperature, yielding the cationic vinylidene complex $\mathbf{6}$, which is unstable at room temperature. An IMDA reaction almost simultaneously occurs between the terminal double bond of the newly added allylic group and the chloroanthracenyl group at room temperature for 6, giving the cationic vinylidene complex 7 with a fused polycyclic ring. After addition of allyl iodide to a solution of $\mathbf{5}$ at room temperature, complexes $\mathbf{6}$ and $\mathbf{7}$ concurrently appeared in $4 \mathrm{~h}$ and the reaction finally afforded 7 as the single product in 3 days. Interestingly, the ${ }^{1} \mathrm{H}$ NMR spectrum of $\mathbf{6}$ obtained from the mixture shows four doublet signals at $\delta 4.65,4.31$ and $\delta 4.43,4.02$ assignable to the protons of the two terminal olefinic $=\mathrm{CH}_{2}$ groups. These signals are shifted noticeably upfield, most likely due to the effect of the ring current of the

(11) (a) Wong, C. Y.; Che, C. M.; Chan, M. C. W.; Leung, K. H. Phillips, D. L.; Zhu, N. J. Am. Chem. Soc. 2004, 126, 2501-2514. (b) Touchard, D.; Pirio, N.; Dixneuf, P. H. Organometallics 1995, 14, 49204928. chloroanthracenyl group. It could be reasonably guessed that both vinyl groups are more or less in the vicinity of the chloroanthracenyl group. However, only the group at $\mathrm{C}_{\beta}$ undergoes the IMDA reaction to yield 7. Analytical and spectroscopic data of complex 7 support the proposed formula. The mass spectrum of 7 exhibits the parent peak at $\mathrm{m} / \mathrm{z}$ 1021.4. The ${ }^{31} \mathrm{P}$ NMR spectrum consists of two doublet resonances, in accordance with the nonequivalent phosphorus nuclei. With two stereogenic carbon centers in 7, this also indicates high diastereoselectivity of the IMDA reaction. In the ${ }^{1} \mathrm{H}$ NMR spectrum of 7, only one allyl group pattern was found. In order to gain further information to support the structure of 7, several 2-D NMR spectra, including COSY, HSQC, HMBC, and NOESY, were obtained. In the COSY spectrum, the multiplet resonance at $\delta 1.76$ assigned to the methyne proton of the fused six-membered ring shows correlations with that of the two saturated internal methylene groups at $\delta 2.48,2.17,1.82$, and 1.46. In the ${ }^{13} \mathrm{C}$ spectrum, resonances of two bridgehead carbons are upfield shifted to $\delta 58.3$ and 71.3 and show no correlation with any proton in the HSQC spectrum. In the HMBC spectrum, the resonance at $\delta 58.3$ shows correlations with that of two protons on the two stereogenic methyne carbons. In the NOESY spectrum, there is a NOE signal between the peaks at $\delta 1.76$ and 4.28 assigned to the two methyne protons of the fivemembered ring, revealing the conformation of complex 7 such that hydrogens on two stereogenic carbon atoms in this ring are in a cis configuration. These NOE results reveal the $R S / S R$ conformation for 7 .

It is interesting to observe that, among two allyl groups, only the group at $\mathrm{C}_{\beta}$ of the vinylidene ligand is involved in the IMDA reaction. The allyl group at $\mathrm{C}_{\gamma}$ is a spectator in the reaction. To better understand if such an IMDA reaction is controlled by the carbon chain length, we therefore carried out the alkylation of 4 with $\mathrm{CH}_{2}=\mathrm{CHCH}_{2} \mathrm{CH}_{2} \mathrm{MgBr}$, yielding the acetylide complex $\mathbf{5 0}$ (see Scheme 1). Attempted allylation of $\mathbf{5 0}$ using hydrous allyl iodide failed to give the desired product. However, 


\section{Scheme 2}

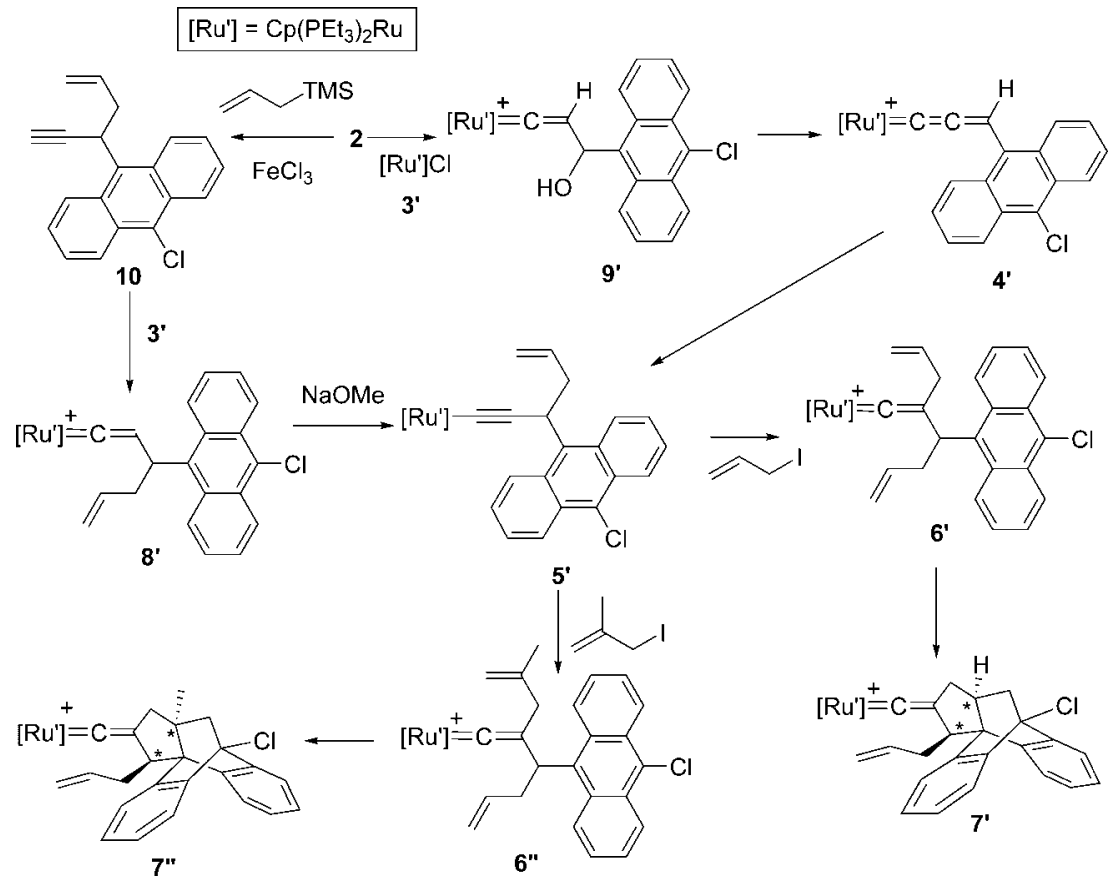

from the reaction, the monosubstituted vinylidene complex $\mathbf{8}$ was obtained in high yield. No allyl group was added at $\mathrm{C}_{\beta}$ on the basis of the spectroscopic and analytical data. The acidic medium used in the reaction possibly caused protonation to take place to give $\mathbf{8}$. Treatment of $\mathbf{5 0}$ with $\mathrm{HBF}_{4}$ indeed afforded $\mathbf{8}$ in high yield. For $\mathbf{8}$ no IMDA reaction was observed, even at elevated temperature. It is therefore assumed that only the allyl group at $\mathrm{C}_{\beta}$ could be utilized as a dienophile for the IMDA reaction. Complex 8 with a butenyl group at $\mathrm{C}_{\gamma}$ has the same number of $\mathrm{C}-\mathrm{C}$ bonds between the terminal vinyl group and the chloroanthrancenyl group as that in 6. Moreover, the chemical shifts of two resonances of terminal olefinic hydrogens at $\delta 5.04$ and 4.99 are in a normal olefinic region. Accordingly, the vinylidene ligand is considered as an essential mediator to bring the chloroanthracenyl group and terminal vinyl group in proximity and the metal fragment may provide an electronic factor to initiate the reaction under mild conditions.

Vinylidene Complexes with $\mathbf{P E t}_{3}$ Ligands. To understand the electronic effect of the metal fragment on this IMDA reaction, we investigated similar reactions of the complex $\left[\mathrm{Ru}^{\prime}\right] \mathrm{Cl}\left(\mathbf{3}^{\prime} ;\left[\mathrm{Ru}^{\prime}\right]=\mathrm{Cp}\left(\mathrm{PEt}_{3}\right)_{2} \mathrm{Ru}\right),{ }^{12}$ containing triethylphosphine ligands. The analogous end product $7^{\prime}$ resulting from the IMDA reaction could be obtained, and an alternative synthetic procedure, as shown in Scheme 2, was also utilized to obtain the desired product.

The reaction of $\mathbf{3}^{\prime}$ with $\mathbf{2}$ for 1 day initially gave a mixture of the allenylidene complex $\mathbf{4}^{\prime}$ and the $\gamma$-hydroxyvinylidene complex $9^{\prime}$. The dehydration process normally occurring in the

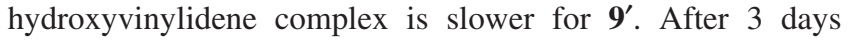
complex $\mathbf{4}^{\prime}$ was obtained as the sole product. The reaction of $\mathbf{4}^{\prime}$ with $\mathrm{CH}_{2}=\mathrm{CHCH}_{2} \mathrm{MgBr}$ then yielded the acetylide complex $\mathbf{5}^{\prime}$. This procedure to yield $\mathbf{5}^{\prime}$ could be achieved by a different method using the enyne compound 10, which was prepared from the reaction of $\mathbf{2}$ with allyltrimethylsilane catalyzed by $\mathrm{FeCl}_{3} \cdot{ }^{13}$ It is known that the coupling reactions of propargylic alcohols

(12) Bruce, M. I.; Hameister, C.; Swincer, A. G.; Wallis, R. C. Inorg. Synth. 1982, 21, 78-82.

(13) Zhan, Z. P.; Yu, J. L.; Liu, H. J.; Cui, Y. Y.; Yang, R. F.; Yang, W. Z.; Li, J. P. J. Org. Chem. 2006, 71, 8298-8301. with allyltrimethylsilane catalyzed by $\mathrm{FeCl}_{3}$ produced substituted 1,5-enynes in high yields. Following the established procedure, treatment of $\mathbf{2}$ with allyltrimethylsilane in the presence of $\mathrm{FeCl}_{3}$ in $\mathrm{CH}_{3} \mathrm{CN}$ afforded the 1,5-enyne $\mathbf{1 0}$ (see Scheme 2). From the ${ }^{1} \mathrm{H}$ NMR spectrum of $\mathbf{1 0}$ the normal coupling constant of 9.2 $\mathrm{Hz}$ between resonances at $\delta 5.35$ and at $\delta 3.16$ and 2.88, assigned to the aliphatic methyne $\mathrm{CH}$ and methylene $\mathrm{CH}_{2}$, respectively, indicates that the allylation takes place at the propargylic site. In the formation of $\mathbf{1 0}$ it was proposed that the dehydroxylation of $\mathbf{2}$ is first induced by $\mathrm{FeCl}_{3}$, yielding a propargylic cation. This is followed by the addition of allyltrimethylsilane to give $\mathbf{1 0}$. Reaction of $\mathbf{3}^{\prime}$ with $\mathbf{1 0}$ in the presence of $\mathrm{KPF}_{6}$ in methanol directly afforded complex $\mathbf{8}^{\prime}$ with an allyl group bonded at $\mathrm{C}_{\gamma}$ of the vinylidene ligand. The reaction of $\mathbf{8}^{\prime}$ with $\mathrm{NaOMe}$ then afforded the acetylide complex $\mathbf{5}^{\prime}$.

Allylation of $\mathbf{5}^{\prime}$ and a subsequent IMDA reaction are similar to those in 5, except the latter reaction required mild thermolysis. When $\mathbf{5}^{\prime}$ was treated with allyl iodide, further allylation took place at $\mathrm{C}_{\beta}$, yielding the cationic vinylidene complex $\mathbf{6}^{\prime}$ with two allyl groups at $\mathrm{C}_{\beta}$ and $\mathrm{C}_{\gamma}$ of the vinylidene ligand. Complex $\mathbf{6}^{\prime}$ in $\mathrm{CH}_{2} \mathrm{Cl}_{2}$ also underwent the IMDA reaction to yield $7^{\prime}$ under mild heating. The ${ }^{31} \mathrm{P}$ NMR spectrum of the mixture displays two sets of two doublet resonances at $\delta 36.28,35.16$ with ${ }^{2} J_{\mathrm{pp}}$ $=33.9 \mathrm{~Hz}$ and at $\delta 38.13,37.48$ with ${ }^{2} J_{\mathrm{pp}}=33.6 \mathrm{~Hz}$, assigned to $\mathbf{6}^{\prime}$ and $\mathbf{7}^{\prime}$, respectively. Additionally treatment of $\mathbf{5}^{\prime}$ with 2-methylallyl iodide afforded the cationic vinylidene complex $6^{\prime \prime}$, which also underwent the IMDA reaction to yield $7^{\prime \prime}$. For complete transformation of $6^{\prime \prime}$ to $7^{\prime \prime}$, a slightly higher temperature, achieved by heating the $\mathrm{CHCl}_{3}$ solution to reflux, was required. Possibly the electron-donating character and the steric effect of the methyl group encumber the approach of this dienophile to diene; therefore, a slightly higher temperature is required for the IMDA reaction of $\mathbf{6}^{\prime \prime}$. The triethylphosphine is a better electron donor ligand than the triphenylphosphine, making the vinylidene ligand of $\mathbf{6}^{\prime}$ more electron rich. It is known that a more electron-rich dienophile should hamper the Diels-Alder reaction, since the strongest interaction takes place between the HOMO of the diene and the LUMO of the dienophile. It is therefore reasonable to assume that if the 
Scheme 3
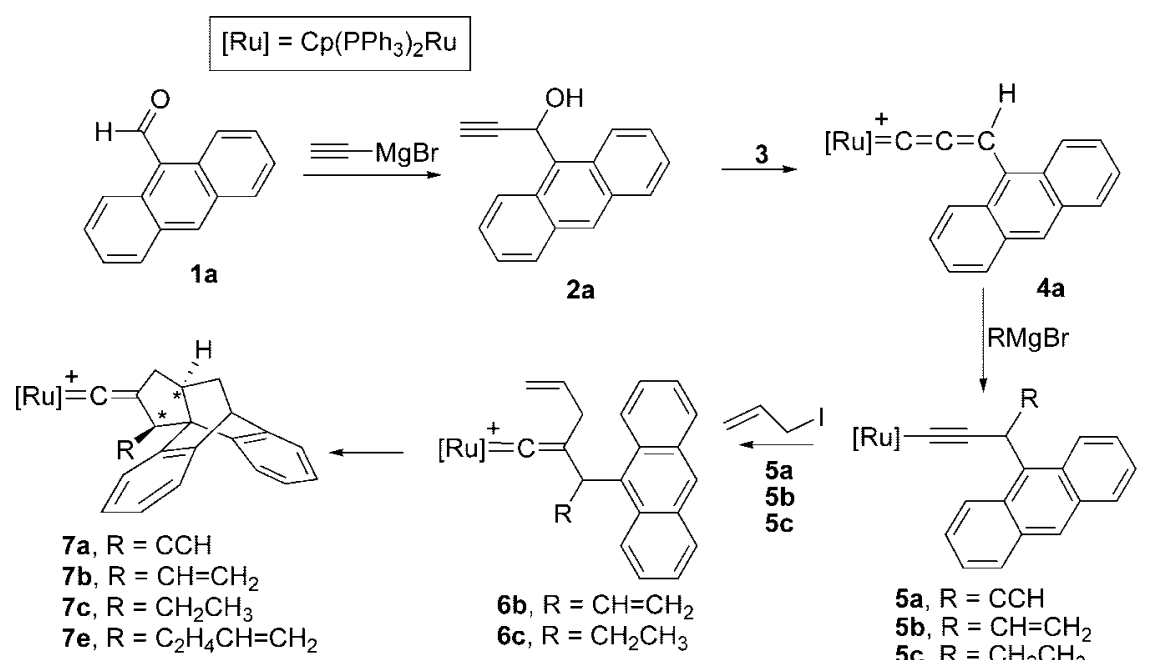

$$
\text { 6b, } \mathrm{R}=\mathrm{CH}=\mathrm{CH}_{2}
$$

5a, $\mathrm{R}=\mathrm{CCH}$

5b, $\mathrm{R}=\mathrm{CH}=\mathrm{CH}_{2}$

5c, $\mathrm{R}=\mathrm{CH}_{2} \mathrm{CH}_{3}$

5e, $\mathrm{R}=\mathrm{C}_{2} \mathrm{H}_{4} \mathrm{CH}=\mathrm{CH}_{2}$

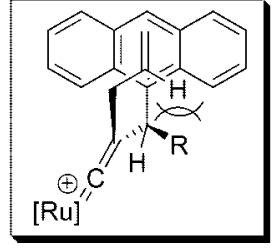

electronic effect is the factor controlling the rate of the IMDA reaction, then the electron-donating triethylphosphine ligand could preferentially make the vinyl group more electron rich. Alternatively, the steric effect could also slow the rate of reaction in the triethylphosphine system, in which the smaller steric bulk of the phosphine ligand may not impede the allyl group to the proximity of the diene.

Effects of Substituents at $\mathrm{C}_{\gamma}$ on the IMDA of the Nonchlorinated Anthracenyl System. The synthetic procedures and reaction products of the nonchlorinated anthracenyl system as shown in Scheme 3 are similar to the chlorinated anthracenyl system of $\mathrm{PPh}_{3}$ mentioned above. In this system, a number of complexes 5a $(\mathrm{R}=\mathrm{C} \equiv \mathrm{CH}), \mathbf{5 b}\left(\mathrm{R}=\mathrm{CH}=\mathrm{CH}_{2}\right), \mathbf{5 c}(\mathrm{R}=$ $\left.\mathrm{CH}_{2} \mathrm{CH}_{3}\right)$, and $\mathbf{5 e}\left(\mathrm{R}=\mathrm{C}_{2} \mathrm{H}_{4} \mathrm{CH}=\mathrm{CH}_{2}\right)$ were prepared to study the effect of substituents at $\mathrm{C}_{\gamma}$ on the rate of reaction. Reaction of $\mathbf{3}$ with $\mathbf{2} \mathbf{a}$, which was obtained from $\mathbf{1 a}$ and $\mathrm{HC} \equiv \mathrm{CMgBr}$, afforded the cationic ruthenium allenylidene complex $\mathbf{4 a}$ as a deep blue powder in high yield. When $\mathbf{4 a}$ was treated with various Grignard reagents $\mathrm{RMgBr}$, the $\mathrm{C}-\mathrm{C}$ bond formation took place at $\mathrm{C}_{\gamma}$ of the allenylidene ligand, yielding the corresponding neutral acetylide complexes $\mathbf{5 a}, \mathbf{5 b}, \mathbf{5 c}$, and $\mathbf{5 e}$ (see Scheme 3). Interestingly, the reaction of $\mathbf{4 a}$ with the allyl Grignard reagent $\mathrm{CH}_{2}=\mathrm{CHCH}_{2} \mathrm{MgBr}$ gave a mixture containing 5d $\left(\mathrm{R}=\mathrm{CH}_{2} \mathrm{CH}=\mathrm{CH}_{2}\right)$ and the product where allylation reaction took place at the central ring of the anthracenyl group in a ratio of 1:2. Attempts to separate these two products by chromatography failed to give the desired product 5d. Thus, the reaction of $\mathbf{5} \mathbf{d}$ was not further investigated. The reaction of 5a with allyl iodide in $\mathrm{CH}_{2} \mathrm{Cl}_{2}$ at room temperature directly afforded the cationic complex 7a, possibly from the IMDA reaction of the allylation intermediate. The intermediate $6 \mathbf{a}$ was not detected. For the same reaction of $\mathbf{5 b}$ with allyl iodide, complex $\mathbf{6 b}$ was observed by NMR and gradually transformed into complex $\mathbf{7 b}$ at room temperature in 3 days. Similar reaction of $\mathbf{5 c}$ with allyl iodide gave $\mathbf{6 c}$, which could be isolated in pure form and was transformed to complex 7c in refluxing $\mathrm{CH}_{2} \mathrm{Cl}_{2}$ in 5 days. The anticipated complex $\mathbf{6 a}$ with an unsaturated alkynyl group is more reactive toward the IMDA reaction in solution than the other two complexes $\mathbf{6 b}$ and $\mathbf{6 c}$, with $\mathbf{6 c}$ being stable at room temperature. This result indicates that the IMDA reaction could be affected by the neighboring group. A nearby unsaturated group promotes the rate of the IMDA reaction. Complexes $\mathbf{7 a}, \mathbf{7 b}$, and $\mathbf{7 c}$ are all stable in solution and have been characterized by spectroscopic data which are similar to those of 7. With a saturated ethyl group, the vinylidene complex 6c was isolated. The downfield triplet $\mathrm{C}_{\alpha}$ resonance at $\delta 358.3$ with ${ }^{2} J_{\mathrm{PC}}=14.7 \mathrm{~Hz}$ in the ${ }^{13} \mathrm{C}$ NMR spectrum indicates the presence of a vinylidene ligand. Two relatively upfield shifted doublet ${ }^{1} \mathrm{H}$ signals at $\delta 4.72$ and 4.12 , again due to the ring current effect of the anthrancenyl group, with coupling constants of 10.7 and $16.9 \mathrm{~Hz}$, respectively, to the internal $=\mathrm{CH}$ are assigned to the terminal allylic $=\mathrm{CH}_{2}$ group.

The attempted allylation reaction of 5e using hydrous allyl iodide again yielded only the protonation product: i.e., the monosubstituted vinylidene complex $\mathbf{8 e}$ in high yield. No allyl group was added at $\mathrm{C}_{\beta}$ if there was a proton source. This result is similar to what was observed in the allylation reaction of $\mathbf{5 0}$ if hydrous iodide was used, yielding only the protonation product 8. For 8e no IMDA reaction was observed even at elevated temperature. The IMDA reaction took place only for the complex with an allyl group at $\mathrm{C}_{\beta}$. Spectroscopic data for complex 8e clearly indicate the character of the vinylidene ligand. A set of two doublet resonances at $\delta 44.06$ and 39.27 with ${ }^{2} J_{\mathrm{PP}}=26.7 \mathrm{~Hz}$ appears in the ${ }^{31} \mathrm{P}$ NMR spectrum of $\mathbf{8 e}$. However, if anhydrous allyl iodide was used, allylation occurred, presumably yielding $\mathbf{6 e}$. Mild thermolysis of $\mathbf{6 e}$ then generated the Diels-Alder product 7e, characterized by spectroscopic data. The only allyl group used for the Diels-Alder reaction is again at $\mathrm{C}_{\beta}$.

Single crystals of the cationic complex $7 \mathrm{c}$ with an $\mathrm{I}_{3}{ }^{-}$anion were obtained in $\mathrm{CH}_{2} \mathrm{Cl}_{2}$ at room temperature. Complex $7 \mathbf{c}$ was characterized by an X-ray crystallographic study with the final residual of refinement R1 (wR2) being 0.0439 (0.0799). An ORTEP type view of the cationic complex $\mathbf{7} \mathbf{c}$ is shown in Figure 1 , and selected bond distances and angles are given in the 


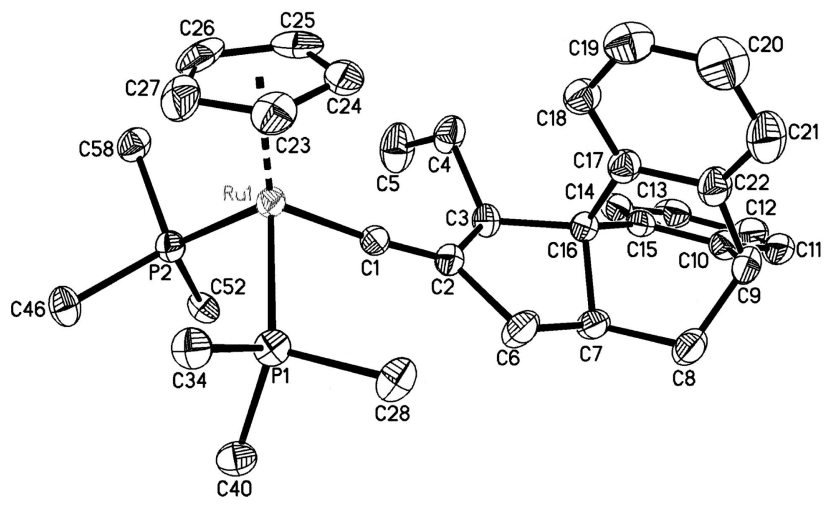

Figure 1. ORTEP drawing of 7c. Phenyl groups, except the C(ipso) atoms on the phosphine ligands, have been omitted for clarity. Selected bond lengths $(\AA)$ and angles (deg): $\operatorname{Ru}(1)-C(1), 1.869(4)$; $\mathrm{Ru}(1)-\mathrm{P}(1), 2.345(1) ; \mathrm{Ru}(1)-\mathrm{P}(2), 2.357(1) ; \mathrm{C}(1)-\mathrm{C}(2), 1.285(5)$; $\mathrm{C}(2)-\mathrm{C}(3), 1.537(5) ; \mathrm{C}(2)-\mathrm{C}(6), 1.551(6) ; \mathrm{C}(3)-\mathrm{C}(4), 1.545(6)$; $\mathrm{C}(3)-\mathrm{C}(16), 1.539(5) ; \mathrm{C}(4)-\mathrm{C}(5), 1.510(6) ; \mathrm{C}(6)-\mathrm{C}(7), 1.526(6)$; $\mathrm{C}(7)-\mathrm{C}(8), 1.530(6) ; \mathrm{C}(7)-\mathrm{C}(16), 1.573(5) ; \mathrm{C}(8)-\mathrm{C}(9), 1.546(6)$; $\mathrm{Ru}(1)-\mathrm{C}(1)-\mathrm{C}(2), 172.5(3) ; \mathrm{C}(1)-\mathrm{C}(2)-\mathrm{C}(3), 129.2(4) ; \mathrm{C}(2)-$ $\mathrm{C}(3)-\mathrm{C}(4), 117.7(3) ; \mathrm{C}(3)-\mathrm{C}(4)-\mathrm{C}(5), 112.6(4) ; \mathrm{P}(1)-\mathrm{Ru}(1)-\mathrm{P}(2)$, 99.67(4); $\mathrm{P}(1)-\mathrm{Ru}(1)-\mathrm{C}(1), 91.00(1) ; \mathrm{P}(2)-\mathrm{Ru}(1)-\mathrm{C}(1), 95.18(1)$

caption to the figure. The molecular structure shows a pseudooctahedral three-legged piano-stool coordination around the ruthenium atom. Construction of the polycyclic structure resulting from the IMDA reaction is clearly seen by the formation of the two new carbon-carbon bonds $\mathrm{C}(7)-\mathrm{C}(16)$ and $\mathrm{C}(8)-\mathrm{C}(9)$. The two stereogenic carbon atoms $\mathrm{C}(3)$ and $\mathrm{C}(7)$ both adopt an $S$ configuration so that the $S S$ form is obtained (the same configuration as that in $\mathbf{7}$ with a chlorine atom). The hydrogen atoms on the two stereogenic carbon atoms in the five-membered ring are in a cis configuration, and this result is consistent with the NOESY spectrum of complex 7. The bond length of $\mathrm{Ru}(1)-\mathrm{C}(1)$ in $7 \mathrm{c}$ is $1.869(4) \AA$, showing a typical $\mathrm{Ru}=\mathrm{C}$ double bond. The $\mathrm{C}(1)-\mathrm{C}(2)$ bond distance of $1.285(5) \AA$ is well within the range of values reported for a $\mathrm{C}=\mathrm{C}$ double bond of a vinylidene ligand. ${ }^{14}$ The $\mathrm{Ru}(1)-\mathrm{C}(1)-\mathrm{C}(2)$ bond angle of $172.5(3)^{\circ}$ shows almost linear geometry. The unique fivemembered ring of the polycyclic ligand adopts an envelope form, with $\mathrm{C}(16)$ bending toward the $\mathrm{Cp}$ ring, causing the bulkier phenyl groups of the anthracenyl ligand to remain in a less crowded region. After the IMDA reaction, the center ring of the anthracenyl part is in a boat conformation and the two phenyl rings are far away from the two triphenylphosphine ligands.

Single crystals of complex $\mathbf{7 b}$ were grown from a diethyl ether $/ \mathrm{CH}_{2} \mathrm{Cl}_{2}$ solution at $-20{ }^{\circ} \mathrm{C}$, and the crystal structure was determined by an X-ray diffraction study. As shown in Figure 2 , the molecular structure of complex $\mathbf{7 b}$ is similar to that of 7c. There is also an envelope form of the five-membered ring, and $\mathrm{C}(13)$ is bent toward the $\mathrm{Cp}$ ring. The diastereoselectivity is also similar to that in the formation of $\mathbf{7}$. The two stereogenic carbon atoms $\mathrm{C}(4)$ and $\mathrm{C}(20)$ adopt an $R$ configuration so that the $R R$ form is obtained. There is no $R S$ form observed in the single crystals. Also, the $\mathrm{C}(21)-\mathrm{C}(22)$ bond distance of the vinyl group is $1.305(7) \AA$, showing a regular $\mathrm{C}=\mathrm{C}$ double bond character.

This IMDA reaction between the allyl group at $\mathrm{C}_{\beta}$ and the anthracenyl group of the vinylidene ligand provides a direct

(14) (a) Le Lagadec, R.; Roman, E.; Toupet, L.; Müller, U.; Dixneuf, P. H. Organometallics 1994, 13, 5030-5039. (b) Sun, Y.; Chan, H. S.; Dixneuf, P. H.; Xie, Z. Organometallics 2006, 25, 2719-2721.

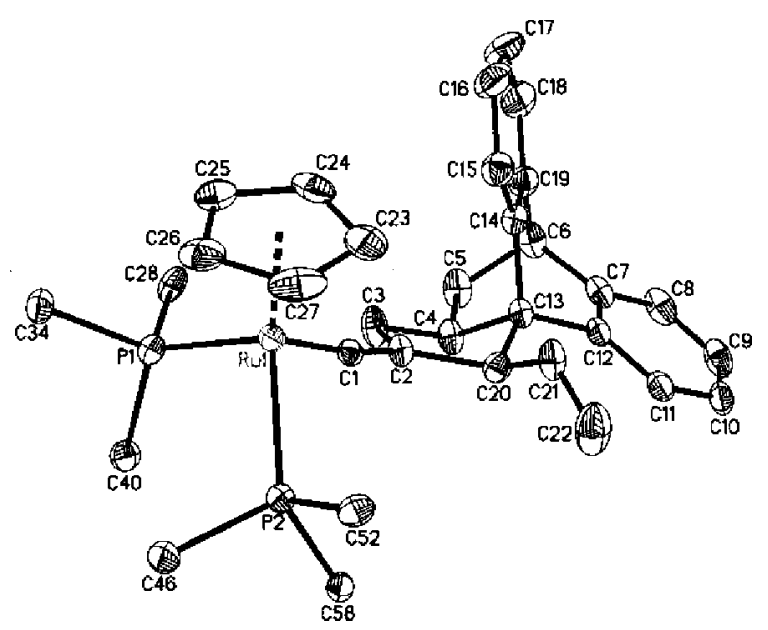

Figure 2. ORTEP drawing of 7b. Phenyl groups, except the C(ipso) atoms on the phosphine ligands, have been omitted for clarity. Selected bond lengths $(\AA)$ and angles (deg): $\mathrm{Ru}(1)-\mathrm{C}(1), 1.867(4)$; $\mathrm{Ru}(1)-\mathrm{P}(1), 2.343(1) ; \mathrm{Ru}(1)-\mathrm{P}(2), 2.364(1) ; \mathrm{C}(1)-\mathrm{C}(2), 1.289(5)$; $\mathrm{C}(2)-\mathrm{C}(3), 1.554(6) ; \mathrm{C}(2)-\mathrm{C}(20), 1.537(6) ; \mathrm{C}(3)-\mathrm{C}(4), 1.522(6)$; $\mathrm{C}(4)-\mathrm{C}(5), 1.547(6) ; \mathrm{C}(4)-\mathrm{C}(13), 1.579(6) ; \mathrm{C}(5)-\mathrm{C}(6), 1.554(6)$; $\mathrm{C}(13)-\mathrm{C}(20), 1.541(6) ; \mathrm{C}(20)-\mathrm{C}(21), 1.505(6) ; \mathrm{C}(21)-\mathrm{C}(22)$, 1.305(7); $\mathrm{Ru}(1)-\mathrm{C}(1)-\mathrm{C}(2), 172.3(3) ; \mathrm{C}(1)-\mathrm{C}(2)-\mathrm{C}(3), 125.6(4)$; $\mathrm{C}(2)-\mathrm{C}(3)-\mathrm{C}(4), 103.9(3) ; \mathrm{C}(3)-\mathrm{C}(4)-\mathrm{C}(5), 118.0(4) ; \mathrm{P}(1)-$ $\mathrm{Ru}(1)-\mathrm{P}(2), 99.66(4) ; \mathrm{P}(1)-\mathrm{Ru}(1)-\mathrm{C}(1), 89.9$ (1); $\mathrm{P}(2)-\mathrm{Ru}(1)-$ $\mathrm{C}(1), 95.2(1)$.

approach to a complex containing a polycyclic ligand under remarkably mild conditions and gives good diastereoselectivity. Only one diastereoisomer was obtained. The solid-state structure provides a rational explanation for the diastereoselectivity of this IMDA reaction. As shown in the lower left square of Scheme 3, the steric effect of the substituent at $\mathrm{C}_{\gamma}$ may control the stereochemistry of the $\mathrm{C}-\mathrm{C}$ bond formation. No IMDA reaction could be observed between the allyl group at $\mathrm{C}_{\gamma}$ and the anthracenyl group.

In a report by Ciganek, ${ }^{7}$ a few 9,12-bridged ethano- and ethenoanthracenes have been obtained by cyclization of 9-substituted anthracenes. These include amides, imines, amines, ethers, thioethers, esters, acetals, and carbinols. These reactions are almost all carried out at high temperature. Some reactions also gave lower yields, due to difficulties in the isolation process. In our case, we carry out the IMDA reaction mostly at room temperature or with mild heating. The reaction is readily monitored by NMR spectroscopy, and the IMDA products are easily isolated. Several attempts by us to use $\mathrm{CH}_{3} \mathrm{CN}, \mathrm{CO}$ and mild oxidizing reagents to remove the organic portion from the vinylidene complexes obtained from IMDA reactions failed to give any isolable product.

Concluding Remarks. Intramolecular Diels-Alder reactions were observed in vinylidene complexes with tethering chloroanthrancenyl/anthrancenyl and vinyl groups under mild conditions. The vinylidene ligand mediates the reaction by bringing the diene and dienenophile close together. The analogous triethylphosphine complex displayed a slower rate of IMDA reaction relative to that for the corresponding triphenylphosphine complex. For vinylidene complexes with a nonchlorinated anthrancenyl group, reactions of three complexes with different substituents nearby revealed the promotional effect of a neighboring unsaturated functional group.

\section{Experimental Section}

General Procedures and Instruments. The manipulations were performed under an atmosphere of dry nitrogen using vacuum-line 
and standard Schlenk techniques. Solvents were dried by standard methods and distilled under nitrogen before use. All reagents were obtained from commercial suppliers and used without further purification. The two ruthenium complexes $\mathrm{Cp}\left(\mathrm{PPh}_{3}\right)_{2} \mathrm{RuCl}(3)$ and $\mathrm{Cp}\left(\mathrm{PEt}_{3}\right)_{2} \mathrm{RuCl}\left(\mathbf{3}^{\prime}\right)$ and compound $\mathbf{2 a}$ were prepared by following the methods reported in the literature. ${ }^{8,9,12}$ The $\mathrm{C}, \mathrm{H}$ analyses were carried out with a Perkin-Elmer 2400 microanalyzer. Mass spectra (FAB) were recorded using a JEOL SX-102A spectrometer; 3-nitrobenzyl alcohol (NBA) was used as the matrix. NMR spectra were recorded on a Bruker AC-300 instrument at $300 \mathrm{MHz}\left({ }^{1} \mathrm{H}\right)$, 121.5 MHz $\left({ }^{31} \mathrm{P}\right)$, or $75.4 \mathrm{MHz}\left({ }^{13} \mathrm{C}\right)$ using $\mathrm{SiMe}_{4}$ or $85 \% \mathrm{H}_{3} \mathrm{PO}_{4}$ as standard or on an Avance 500 FT-NMR spectrometer.

Synthesis of 2. To a solution of 10-chloro-9-anthraldehyde (1; $1.02 \mathrm{~g}, 4.23 \mathrm{mmol})$ in $10 \mathrm{~mL}$ of THF was added $\mathrm{HC} \equiv \mathrm{CMgBr}(15$ $\mathrm{mL}, 0.5 \mathrm{M}$ in THF) at $-78{ }^{\circ} \mathrm{C}$, and the resulting solution was stirred at room temperature for $12 \mathrm{~h}$. The solvent was removed under reduced pressure. An aliquot of water $(100 \mathrm{~mL})$ was added to the mixture, and the product was extracted with diethyl ether $(3 \times 100$ $\mathrm{mL})$. The organic layer was washed with water $(2 \times 100 \mathrm{~mL})$ and dried with $\mathrm{MgSO}_{4}$. Solvent was removed under vacuum to give 2 (0.94 g, 85\% yield). Anal. Calcd for $\mathrm{C}_{17} \mathrm{H}_{11} \mathrm{ClO}$ : C, 76.55; H, 4.16 . Found: C, 76.39; H, 4.08. ${ }^{1} \mathrm{H}$ NMR $\left(\mathrm{CDCl}_{3}\right): \delta 8.64\left(\mathrm{~d}, 2 \mathrm{H},{ }^{3} \mathrm{~J}_{\mathrm{HH}}\right.$ $=7.3 \mathrm{~Hz}$, anthracene), $8.56\left(\mathrm{~d}, 2 \mathrm{H},{ }^{3} J_{\mathrm{HH}}=7.3 \mathrm{~Hz}\right.$, anthracene $)$, $7.60-7.52\left(\mathrm{~m}, 4 \mathrm{H}\right.$, anthracene), $6.91\left(\mathrm{~d}, 1 \mathrm{H},{ }^{3} \mathrm{~J}_{\mathrm{HH}}=2.3 \mathrm{~Hz}, \mathrm{CH}\right)$, 2.87 (br s, $1 \mathrm{H}, \mathrm{OH}), 2.66\left(\mathrm{~d}, 1 \mathrm{H},{ }^{3} \mathrm{~J}_{\mathrm{HH}}=2.3 \mathrm{~Hz}, \mathrm{CH}\right) .{ }^{13} \mathrm{C}\left\{{ }^{1} \mathrm{H}\right\}$ NMR $\left(\mathrm{CDCl}_{3}\right): \delta$ 131.3-124.7 (anthracene), 83.7 (三C), 75.7 (三CH), $59.0(\mathrm{CH})$. MS m/z: $265.9\left(\mathrm{M}^{+}\right)$.

Synthesis of 10. To a solution of $2(2.51 \mathrm{~g}, 9.41 \mathrm{mmol})$ in $\mathrm{CH}_{3} \mathrm{CN}(10 \mathrm{~mL})$ were added allyltrimethylsilane $(3.42 \mathrm{~g}, 30 \mathrm{mmol})$ and $\mathrm{FeCl}_{3}(0.16 \mathrm{~g}, 10 \mathrm{~mol} \%)$ successively. The solution was stirred at room temperature for $10 \mathrm{~h}$. The solvent was removed under vacuum, and the product was purified by silica gel column chromatography with hexane as eluent. The solvent of the yellow band was removed under vacuum to give $\mathbf{1 0}$ (1.67 g, 61\% yield). Anal. Calcd for $\mathrm{C}_{20} \mathrm{H}_{15} \mathrm{Cl}$ : C, 82.61; H, 5.20. Found: C, 82.73; H, 5.54. ${ }^{1} \mathrm{H}$ NMR $\left(\mathrm{CDCl}_{3}, 400 \mathrm{MHz}\right): \delta 8.71-8.67(\mathrm{~m}, 4 \mathrm{H}$, anthracene), 7.66-7.57 (m, 4H, anthracene), $6.01(\mathrm{~m}, 1 \mathrm{H},=\mathrm{CH})$, $5.35(\mathrm{~m}, 1 \mathrm{H}, \mathrm{CH}), 5.24\left(\mathrm{~d}, 1 \mathrm{H},{ }^{3} J_{\mathrm{HH}}=17.0 \mathrm{~Hz}\right.$, trans $\left.=\mathrm{CH}_{2}\right), 5.14$ $\left(\mathrm{d}, 1 \mathrm{H},{ }^{3} \mathrm{~J}_{\mathrm{HH}}=10.9 \mathrm{~Hz}\right.$, cis $\left.=\mathrm{CH}_{2}\right), 3.25\left(\mathrm{~m}, 1 \mathrm{H}, \mathrm{CH}_{2}\right), 2.88(\mathrm{~m}$, $\left.1 \mathrm{H}, \mathrm{CH}_{2}\right), 2.48\left(\mathrm{~d}, 1 \mathrm{H},{ }^{4} \mathrm{~J}_{\mathrm{HH}},=2.7 \mathrm{~Hz}, \equiv \mathrm{CH}\right) .{ }^{13} \mathrm{C}\left\{{ }^{1} \mathrm{H}\right\} \mathrm{NMR}$ $\left(\mathrm{CDCl}_{3}\right): \delta 135.4(=\mathrm{CH}), 131.6-125.3$ (anthracene), $116.1\left(=\mathrm{CH}_{2}\right)$, $85.8(\equiv \mathrm{C}), 72.01(\equiv \mathrm{CH}), 40.4\left(\mathrm{CH}_{2}\right), 31.4(\mathrm{CH}) . \mathrm{MS}: \mathrm{m} / \mathrm{z} 289.9$ $\left(\mathrm{M}^{+}\right)$.

Preparation of $\left\{[\mathbf{R u}]=\mathrm{C}=\mathrm{C}=\mathrm{CH}\left(\mathbf{9}-\mathrm{Cl}-\mathbf{1 0}-\mathrm{C}_{14} \mathrm{H}_{8}\right)\right\}\left[\mathrm{PF}_{6}\right]$ (4). To a Schlenk flask charged with complex $3(0.55 \mathrm{~g}, 0.75 \mathrm{mmol})$ and $\mathrm{KPF}_{6}(0.65 \mathrm{~g}, 3.53 \mathrm{mmol})$ was added methanol $(20 \mathrm{~mL})$ under nitrogen. Then, $2(0.27 \mathrm{~g}, 1.01 \mathrm{mmol})$ was added and the resulting solution was stirred at room temperature for $5 \mathrm{~h}$. The color of the solution changed from orange to dark blue. After the solvent was removed under vacuum, $30 \mathrm{~mL}$ of $\mathrm{CH}_{2} \mathrm{Cl}_{2}$ was added. The solution was filtered through Celite, and the volume of the solution was reduced to $7 \mathrm{~mL}$ under vacuum. Then $60 \mathrm{~mL}$ of hexane was added to cause precipitation of a deep blue powder. After filtration, the precipitate was washed with $10 \mathrm{~mL}$ of hexane twice and then dried under vacuum to give the product $4(0.71 \mathrm{~g}, 87 \%$ yield $)$. Anal. Calcd for $\mathrm{C}_{58} \mathrm{H}_{44} \mathrm{ClF}_{6} \mathrm{P}_{3} \mathrm{Ru}$ : C, 64.24; $\mathrm{H}, 4.09$. Found: $\mathrm{C}, 64.37 ; \mathrm{H}$, 4.30. ${ }^{1} \mathrm{H}$ NMR $\left(\mathrm{CDCl}_{3}\right): \delta 10.74\left(\mathrm{~s},=\mathrm{C}_{\gamma} \mathrm{H}\right), 9.10\left(\mathrm{~d}, 2 \mathrm{H},{ }^{3} J_{\mathrm{HH}}=\right.$ $8.8 \mathrm{~Hz}$, anthracene), $8.73\left(\mathrm{~d}, 2 \mathrm{H},{ }^{3} J_{\mathrm{HH}}=8.8 \mathrm{~Hz}\right.$, anthracene), 7.75 $\left(\mathrm{t}, 2 \mathrm{H},{ }^{3} J_{\mathrm{HH}}=8.3 \mathrm{~Hz}\right.$, anthracene), $7.65\left(\mathrm{t}, 2 \mathrm{H},{ }^{3} J_{\mathrm{HH}}=8.3 \mathrm{~Hz}\right.$, anthracene), 7.33-7.07 (m, 30H, Ph), 5.14 (s, 5H, Cp). ${ }^{13} \mathrm{C}\left\{{ }^{1} \mathrm{H}\right\}$ $\operatorname{NMR}\left(\mathrm{CDCl}_{3}\right): \delta 305.3\left(\mathrm{t},{ }^{2} J_{\mathrm{PC}}=18.1 \mathrm{~Hz}, \mathrm{C}_{\alpha}\right), 146.4\left(\mathrm{C}_{\beta}\right), 137.9$ $\left(\mathrm{C}_{\gamma}\right), 135.2-125.2\left(\mathrm{Ph}\right.$, anthracene), $93.7(\mathrm{Cp}) .{ }^{31} \mathrm{P} \mathrm{NMR}\left(\mathrm{CDCl}_{3}\right)$ : $\delta 46.13$ (s). MS: $m / z, 939.2\left(\mathrm{M}^{+}\right)$.

Preparation of $\left\{\left[\mathrm{Ru}^{\prime}\right]=\mathrm{C}=\mathrm{C}=\mathrm{CH}\left(\mathbf{9}-\mathrm{Cl}-10-\mathrm{C}_{14} \mathrm{H}_{8}\right)\right\}\left[\mathrm{PF}_{6}\right]\left(4^{\prime}\right)$. To a Schlenk flask charged with complex $\mathbf{3}^{\prime}(0.10 \mathrm{~g}, 0.23 \mathrm{mmol})$ and $\mathrm{KPF}_{6}(0.13 \mathrm{~g}, 0.71 \mathrm{mmol})$ was added $\mathrm{CH}_{2} \mathrm{Cl}_{2}(10 \mathrm{~mL})$ under nitrogen. Then, $2(0.14 \mathrm{~g}, 9.52 \mathrm{mmol})$ was added and the resulting solution was stirred at room temperature for $12 \mathrm{~h}$. The color of the solution changed from orange to dark blue. After the solvent was removed under vacuum, $30 \mathrm{~mL}$ of $\mathrm{CH}_{2} \mathrm{Cl}_{2}$ was added. The solution was filtered through Celite, and the volume of the solution was reduced to $5 \mathrm{~mL}$ under vacuum. Then $60 \mathrm{~mL}$ of hexane was added to cause precipitation of a deep blue powder. After filtration, the precipitate was washed with $10 \mathrm{~mL}$ of hexane twice and then dried under vacuum to give the product $4^{\prime}$ ( $0.16 \mathrm{~g}, 86 \%$ yield). Anal. Calcd for $\mathrm{C}_{34} \mathrm{H}_{44} \mathrm{ClF}_{6} \mathrm{P}_{3} \mathrm{Ru}$ : C, 51.29; H, 5.57. Found: C, 51.39; $\mathrm{H}$, 5.66. ${ }^{1} \mathrm{H} \mathrm{NMR}\left(\mathrm{CDCl}_{3}\right): \delta 10.55\left(\mathrm{~s},=\mathrm{C}_{\gamma} \mathrm{H}\right), 9.21\left(\mathrm{~d}, 2 \mathrm{H},{ }^{3} J_{\mathrm{HH}}=\right.$ $8.9 \mathrm{~Hz}$, anthracene), $8.72\left(\mathrm{~d}, 2 \mathrm{H},{ }^{3} J_{\mathrm{HH}}=8.9 \mathrm{~Hz}\right.$, anthracene $), 7.88$ $\left(\mathrm{t}, 2 \mathrm{H},{ }^{3} J_{\mathrm{HH}}=7.8 \mathrm{~Hz}\right.$, anthracene $), 7.65\left(\mathrm{t}, 2 \mathrm{H},{ }^{3} J_{\mathrm{HH}}=7.8 \mathrm{~Hz}\right.$, anthracene), 5.50 (s, 5H, Cp), 2.06-1.69 (m, 12H, $\left.\mathrm{CH}_{2}\right), 1.17-0.99$ $\left(\mathrm{m}, 18 \mathrm{H}, \mathrm{CH}_{3}\right) .{ }^{31} \mathrm{P}$ NMR $\left(\mathrm{CDCl}_{3}\right): \delta 39.36(\mathrm{~s}) . \mathrm{MS}: \mathrm{m} / \mathrm{z} 651.2$ $\left(\mathrm{M}^{+}\right)$.

Preparation of $\left\{[\mathrm{Ru}]=\mathrm{C}=\mathrm{C}=\mathrm{CH}\left(\mathrm{C}_{14} \mathrm{H}_{9}\right)\right\}\left[\mathrm{PF}_{6}\right]$ (4a). Compound 4a was prepared from complex $3(0.50 \mathrm{~g}, 0.69 \mathrm{mmol}), \mathrm{KPF}_{6}$ (0.65 g, $3.53 \mathrm{mmol})$, and 2a $(0.23 \mathrm{~g}, 0.99 \mathrm{mmol})$ using the same procedure as that for 4 . The product $4 \mathbf{a}(0.63 \mathrm{~g})$ was isolated in $86 \%$ yield. Anal. Calcd for $\mathrm{C}_{58} \mathrm{H}_{45} \mathrm{~F}_{6} \mathrm{P}_{3} \mathrm{Ru}$ : C, 66.35; $\mathrm{H}, 4.32$. Found: $\mathrm{C}, 66.71 ; \mathrm{H}, 4.45 .{ }^{1} \mathrm{H}$ NMR $\left(\mathrm{CDCl}_{3}\right): \delta 10.52\left(\mathrm{~s},=\mathrm{C}_{\gamma} \mathrm{H}\right), 9.17(\mathrm{~d}$, $2 \mathrm{H},{ }^{3} J_{\mathrm{HH}}=9.0 \mathrm{~Hz}$, anthracene $), 9.08(\mathrm{~s}, 1 \mathrm{H}$, anthracene $), 8.17(\mathrm{~d}$, $2 \mathrm{H},{ }^{3} J_{\mathrm{HH}}=9.0 \mathrm{~Hz}$, anthracene $), 7.78\left(\mathrm{t}, 2 \mathrm{H},{ }^{3} J_{\mathrm{HH}}=8.2 \mathrm{~Hz}\right.$, anthracene), $7.54\left(\mathrm{t}, 2 \mathrm{H},{ }^{3} J_{\mathrm{HH}}=8.2 \mathrm{~Hz}\right.$, anthracene), 7.31-7.07 $(\mathrm{m}, 30 \mathrm{H}, \mathrm{Ph}), 5.07(\mathrm{~s}, 5 \mathrm{H}, \mathrm{Cp}) .{ }^{13} \mathrm{C}\left\{{ }^{1} \mathrm{H}\right\} \mathrm{NMR}\left(\mathrm{CDCl}_{3}\right): \delta 301.0(\mathrm{t}$, $\left.{ }^{2} J_{\mathrm{PC}}=17.5 \mathrm{~Hz}, \mathrm{C}_{\alpha}\right), 216.6\left(\mathrm{C}_{\beta}\right), 146.2\left(\mathrm{C}_{\gamma}\right), 135.1-124.3(\mathrm{Ph}$, anthracene), $93.2(\mathrm{Cp}) .{ }^{31} \mathrm{P}$ NMR $\left(\mathrm{CDCl}_{3}\right): \delta 46.35$ (s). MS: $\mathrm{m} / \mathrm{z}$ $905.2\left(\mathrm{M}^{+}\right)$.

Preparation of $[\mathrm{Ru}] \mathrm{C} \equiv \mathrm{CCH}\left(9-\mathrm{Cl}-10-\mathrm{C}_{14} \mathrm{H}_{8}\right) \mathrm{CH}_{\mathbf{2}} \mathrm{CH}=\mathrm{CH}_{\mathbf{2}}$ (5). A solution of $4(0.22 \mathrm{~g}, 0.20 \mathrm{mmol})$ in $10 \mathrm{~mL}$ of THF at -78 ${ }^{\circ} \mathrm{C}$ was treated with $\mathrm{CH}_{2}=\mathrm{CHCH}_{2} \mathrm{MgBr}(2 \mathrm{~mL}, 1.0 \mathrm{M}$ in THF $)$ until the color turned to yellow. The mixture was stirred for 30 min while the temperature was slowly increased to $0{ }^{\circ} \mathrm{C}$, and the solvent was removed. The residue was extracted with $4 \times 5 \mathrm{~mL}$ of ether and filtered through Celite. The yellow solution was concentrated to give a light yellow powder. The precipitate was filtered and washed with cold $\mathrm{MeOH}(10 \mathrm{~mL})$ and dried under vacuum to give 5 (0.15 g, 76\% yield). Anal. Calcd for $\mathrm{C}_{61} \mathrm{H}_{49} \mathrm{ClP}_{2} \mathrm{Ru}$ : C, 74.72; $\mathrm{H}, 5.04$. Found: $\mathrm{C}, 74.81 ; \mathrm{H}, 5.11 .{ }^{1} \mathrm{H} \mathrm{NMR}\left(\mathrm{CDCl}_{3}\right): \delta 8.61(\mathrm{~m}$, $2 \mathrm{H}$, anthracene), 7.50-6.66 (m, 36H, Ph), $5.99(\mathrm{~m}, 1 \mathrm{H},=\mathrm{CH})$, $5.39(\mathrm{~m}, 1 \mathrm{H}, \mathrm{CH}), 5.04-4.82\left(\mathrm{~m}, 2 \mathrm{H},=\mathrm{CH}_{2}\right), 4.22(\mathrm{~s}, 5 \mathrm{H}, \mathrm{Cp})$, $3.15\left(\mathrm{~m}, 1 \mathrm{H}, \mathrm{CH}_{2}\right), 2.60\left(\mathrm{~m}, 1 \mathrm{H}, \mathrm{CH}_{2}\right) .{ }^{13} \mathrm{C}\left\{{ }^{1} \mathrm{H}\right\} \mathrm{NMR}\left(\mathrm{CDCl}_{3}\right): \delta$ 139.7-123.6 $\left(\mathrm{Ph}\right.$, anthracene, $\left.\mathrm{CCH}_{2}\right), 114.9\left(=\mathrm{CH}_{2}\right), 112.1\left(\mathrm{C}_{\beta}\right)$, $97.2\left(\mathrm{t},{ }^{2} J_{\mathrm{PC}}=25.3 \mathrm{~Hz}, \mathrm{C}_{\alpha}\right), 84.9(\mathrm{Cp}), 42.6\left(\mathrm{CH}_{2}\right), 35.5(\mathrm{CH}) .{ }^{31} \mathrm{P}$ $\mathrm{NMR}\left(\mathrm{CDCl}_{3}\right): \delta 51.62,50.70\left(2 \mathrm{~d},{ }^{2} J_{\mathrm{PP}}=37.2 \mathrm{~Hz}, \mathrm{PPh}_{3}\right)$. MS: $m / z, 981.2\left(\mathrm{M}^{+}\right)$.

Preparation of $[\mathrm{Ru}] \mathrm{C} \equiv \mathrm{CCH}\left(9-\mathrm{Cl}-10-\mathrm{C}_{14} \mathrm{H}_{8}\right) \mathrm{CH}_{2} \mathrm{CH}_{2} \mathrm{CH}=$ $\mathbf{C H}_{2}$ (50). Complex $\mathbf{5 0}(0.13 \mathrm{~g}, 85 \%$ yield $)$ was similarly prepared from $4(0.11 \mathrm{~g}, 0.10 \mathrm{mmol})$ and $\mathrm{CH}_{2}=\mathrm{CHCH}_{2} \mathrm{CH}_{2} \mathrm{MgBr}(2 \mathrm{~mL}$, 0.5 M in THF). Anal. Calcd for $\mathrm{C}_{62} \mathrm{H}_{51} \mathrm{ClP}_{2} \mathrm{Ru}$ : C, 74.88; H, 5.17. Found: C, 74.72; H, 5.20. ${ }^{1} \mathrm{H} \mathrm{NMR}\left(\mathrm{CDCl}_{3}\right): \delta 9.86\left(\mathrm{~d}, 1 \mathrm{H},{ }^{3} \mathrm{~J}_{\mathrm{HH}}\right.$ $=9.0 \mathrm{~Hz}$, anthracene $), 8.59\left(\mathrm{~d}, 2 \mathrm{H},{ }^{3} J_{\mathrm{HH}}=8.9 \mathrm{~Hz}\right.$, anthracene $)$, $8.37\left(\mathrm{~d}, 1 \mathrm{H},{ }^{3} J_{\mathrm{HH}}=8.8 \mathrm{~Hz}\right.$, anthracene $), 7.50-6.63(\mathrm{~m}, 34 \mathrm{H}, \mathrm{Ph}$, anthracene), $5.83(\mathrm{~m}, 1 \mathrm{H},=\mathrm{CH}), 5.35(\mathrm{~m}, 1 \mathrm{H}, \mathrm{CH}), 4.90(\mathrm{~d}, 1 \mathrm{H}$, ${ }^{3} J_{\mathrm{HH}}=9.6 \mathrm{~Hz}$, cis $\left.=\mathrm{CH}_{2}\right), 4.88\left(\mathrm{~d}, 1 \mathrm{H},{ }^{3} J_{\mathrm{HH}}=16.8 \mathrm{~Hz}\right.$, trans $\left.=\mathrm{CH}_{2}\right), 4.20(\mathrm{~s}, 5 \mathrm{H}, \mathrm{Cp}), 2.50\left(\mathrm{~m}, 2 \mathrm{H}, \mathrm{CH}_{2}\right), 2.18\left(\mathrm{~m}, 1 \mathrm{H}, \mathrm{CH}_{2}\right)$, $1.85\left(\mathrm{~m}, 1 \mathrm{H}, \mathrm{CH}_{2}\right) \cdot{ }^{13} \mathrm{C}\left\{{ }^{1} \mathrm{H}\right\} \mathrm{NMR}\left(\mathrm{CDCl}_{3}\right): \delta 139.7-124.6(\mathrm{~s}, \mathrm{Ph}$, anthracene, $=\mathrm{CH}), 114.5\left(\mathrm{C}_{\beta}\right), 112.1\left(=\mathrm{CH}_{2}\right), 96.9\left(\mathrm{t},{ }^{2} J_{\mathrm{PC}}=25.0\right.$ $\left.\mathrm{Hz}, \mathrm{C}_{\alpha}\right), 84.8(\mathrm{Cp}), 37.2\left(\mathrm{CH}_{2}\right), 34.5\left(\mathrm{CH}_{2}\right), 32.8(\mathrm{CH}) .{ }^{31} \mathrm{P} \mathrm{NMR}$ $\left(\mathrm{CDCl}_{3}\right): \delta 51.74,50.72\left(\right.$ two d, $\left.{ }^{2} J_{\mathrm{pp}}=36.9 \mathrm{~Hz}, \mathrm{PPh}_{3}\right) . \mathrm{MS}: \mathrm{m} / z$ $994.3\left(\mathrm{M}^{+}\right)$.

Preparation of $\left[\mathrm{Ru}^{\prime}\right] \mathrm{C} \equiv \mathrm{CCH}\left(\mathbf{9}-\mathrm{Cl}-10-\mathrm{C}_{14} \mathrm{H}_{8}\right) \mathrm{CH}_{\mathbf{2}} \mathrm{CH}=\mathrm{CH}_{2}$ (5'). To a Schlenk flask charged with complex $\mathbf{8}^{\prime}(0.20 \mathrm{~g}, 0.24 \mathrm{mmol}$ see below) was added a solution of $\mathrm{NaOMe}(0.13 \mathrm{~g}, 2.4 \mathrm{mmol})$ in methanol $(5 \mathrm{~mL})$ under nitrogen. The solution was stirred at room temperature for $5 \mathrm{~min}$, and the color changed from orange to yellow. The solvent was removed under vacuum. The product was extracted 
with $4 \times 5 \mathrm{~mL}$ of $\mathrm{CH}_{2} \mathrm{Cl}_{2}$ and filtered through Celite. The solvent of the filtrate was removed under vacuum to give the product $\mathbf{5}^{\prime}$ (0.12 g, 73\% yield). Anal. Calcd for $\mathrm{C}_{37} \mathrm{H}_{49} \mathrm{ClP}_{2} \mathrm{Ru}$ : C, 64.20; $\mathrm{H}$, 7.13. Found: C, 64.31; H, 7.28. ${ }^{1} \mathrm{H} \mathrm{NMR}\left(\mathrm{CDCl}_{3}\right): \delta 8.53(\mathrm{~d}, 2 \mathrm{H}$, ${ }^{3} J_{\mathrm{HH}}=8.8 \mathrm{~Hz}$, anthracene), 7.56-7.42 (m, 6H, anthracene), 5.91 $(\mathrm{m}, 1 \mathrm{H}, C=\mathrm{CH}), 5.38\left(\mathrm{t},{ }^{3} J_{\mathrm{HH}}=7.7 \mathrm{~Hz}, 1 \mathrm{H}, \mathrm{CH}\right), 4.97-4.82(\mathrm{~m}$, $\left.2 \mathrm{H},=\mathrm{CH}_{2}\right), 4.59(\mathrm{~s}, 5 \mathrm{H}, \mathrm{Cp}), 3.09-2.63\left(\mathrm{~m}, 2 \mathrm{H},=\mathrm{CCH}_{2}\right)$, $1.80-1.17\left(\mathrm{~m}, 12 \mathrm{H}, \mathrm{CH}_{2}\right), 0.91-0.75\left(\mathrm{~m}, 18 \mathrm{H}, \mathrm{CH}_{3}\right) .{ }^{31} \mathrm{P} \mathrm{NMR}$ $\left(\mathrm{CDCl}_{3}\right): \delta 40.77,40.46\left(2 \mathrm{~d},{ }^{2} J_{\mathrm{pp}}=39.4 \mathrm{~Hz}, \mathrm{PEt}_{3}\right)$. MS: $\mathrm{m} / z 692.6$ $\left(\mathrm{M}^{+}\right)$.

Preparation of $[\mathrm{Ru}] \mathrm{C} \equiv \mathrm{CCH}\left(\mathbf{9}-\mathrm{Cl}-10-\mathrm{C}_{14} \mathrm{H}_{8}\right) \mathrm{C} \equiv \mathrm{CH}$ (5a). A solution of $4 \mathbf{a}(0.22 \mathrm{~g}, 0.21 \mathrm{mmol})$ in $10 \mathrm{~mL}$ of THF at $-78{ }^{\circ} \mathrm{C}$ was treated with $\mathrm{HC} \equiv \mathrm{CMgBr}(4 \mathrm{~mL}, 0.5 \mathrm{M}$ in THF) until the color turned to yellow. The mixture was stirred for $30 \mathrm{~min}$ while the temperature was slowly increased to $0{ }^{\circ} \mathrm{C}$, and the solvent was removed. The product was extracted with $4 \times 5 \mathrm{~mL}$ of ether and filtered through Celite. The solvent was removed under vacuum to give 5a $(0.17 \mathrm{~g}, 90 \%)$. Anal. Calcd for $\mathrm{C}_{60} \mathrm{H}_{46} \mathrm{P}_{2} \mathrm{Ru}$ : C, 77.49; $\mathrm{H}$, 4.99. Found: $\mathrm{C}, 77.45 ; \mathrm{H}, 5.05 .{ }^{1} \mathrm{H} \mathrm{NMR}\left(\mathrm{CDCl}_{3}\right): \delta 8.39(\mathrm{~s}, 1 \mathrm{H}$, anthracene), $7.98\left(\mathrm{~d}, 2 \mathrm{H},{ }^{3} \mathrm{~J}_{\mathrm{HH}}=8.4 \mathrm{~Hz}\right.$, anthracene), 7.44-6.62 (m, 36H, Ph, anthracene), 6.39 (br s, 1H, CH), 4.15 (s, 5H, Cp), $2.28\left(\mathrm{~d}, 1 \mathrm{H},{ }^{3} \mathrm{~J}_{\mathrm{HH}}=2.6 \mathrm{~Hz}, \mathrm{C} \equiv \mathrm{CH}\right) .{ }^{13} \mathrm{C}\left\{{ }^{1} \mathrm{H}\right\} \mathrm{NMR}\left(\mathrm{CDCl}_{3}\right): \delta$ $139.1-124.7(\mathrm{~s}, \mathrm{Ph}$, anthracene, $=\mathrm{CH}), 105.4\left(\mathrm{C}_{\beta}\right), 99.2\left(\mathrm{t},{ }^{2} J_{\mathrm{PC}}=\right.$ $\left.25.0 \mathrm{~Hz}, \mathrm{C}_{\alpha}\right), 86.7(\equiv \mathrm{C}), 84.9(\mathrm{Cp}), 81.4(\equiv \mathrm{CH}), 30.2(\mathrm{CH}) .{ }^{31} \mathrm{P}$ $\operatorname{NMR}\left(\mathrm{CDCl}_{3},\right): \delta 51.30,50.87\left(2 \mathrm{~d},{ }^{2} J_{\mathrm{PP}}=36.5 \mathrm{~Hz}, \mathrm{PPh}_{3}\right)$. MS ESI $m / z$ : $931.2\left(\mathrm{M}^{+}\right)$.

Preparation of $[\mathrm{Ru}] \mathrm{C} \equiv \mathrm{CCH}\left(\mathrm{C}_{\mathbf{1 4}} \mathbf{H}_{\mathbf{9}}\right) \mathbf{C H}=\mathrm{CH}_{\mathbf{2}}(\mathbf{5 b})$. A solution of $4 \mathbf{a}(0.22 \mathrm{~g}, 0.21 \mathrm{mmol})$ in $10 \mathrm{~mL}$ of THF at $-78{ }^{\circ} \mathrm{C}$ was treated with $\mathrm{CH}_{2}=\mathrm{CHMgBr}(3 \mathrm{~mL}, 0.7 \mathrm{M}$ in THF $)$ until the color turned to yellow. The mixture was stirred for $30 \mathrm{~min}$ while the temperature was slowly increased to $0{ }^{\circ} \mathrm{C}$, and the solvent was removed. The residue was extracted with $4 \times 5 \mathrm{~mL}$ of ether and filtered through Celite. The yellow solution was concentrated to give a light yellow powder. The precipitate was filtered and washed with cold $\mathrm{MeOH}$ $(10 \mathrm{~mL})$ and dried under vacuum to give $\mathbf{5 b}(0.16 \mathrm{~g}, 80 \%)$. Anal. Calcd for $\mathrm{C}_{60} \mathrm{H}_{48} \mathrm{P}_{2} \mathrm{Ru}$ : C, 77.32; H, 5.19. Found: C, 77.51; H, 5.24. ${ }^{1} \mathrm{H} \mathrm{NMR}\left(\mathrm{CDCl}_{3}\right): \delta 8.39\left(\mathrm{~s}, 1 \mathrm{H}\right.$, anthracene), $8.38\left(\mathrm{~d}, 2 \mathrm{H},{ }^{3} J_{\mathrm{HH}}=\right.$ $8.4 \mathrm{~Hz}$, anthracene), 7.49-6.61 (m, 36H, Ph, anthracene), 6.25 (m, $1 \mathrm{H},=\mathrm{CH}), 6.13(\mathrm{br}, 1 \mathrm{H}, \mathrm{CH}), 6.03\left(\mathrm{~d}, 1 \mathrm{H},{ }^{3} J_{\mathrm{HH}}=17.1 \mathrm{~Hz}\right.$, trans $\left.=\mathrm{CH}_{2}\right), 5.29\left(\mathrm{~d}, 1 \mathrm{H},{ }^{3} \mathrm{~J}_{\mathrm{HH}}=11.1 \mathrm{~Hz}\right.$, cis $\left.=\mathrm{CH}_{2}\right), 4.22(\mathrm{~s}, 5 \mathrm{H}, \mathrm{Cp})$. ${ }^{13} \mathrm{C}\left\{{ }^{1} \mathrm{H}\right\}$ NMR $\left(\mathrm{CDCl}_{3}\right): \delta 142.6-124.4(\mathrm{~s}, \mathrm{Ph}$, anthracene, $=\mathrm{CH})$, $113.3\left(C_{\beta}\right), 109.3\left(=\mathrm{CH}_{2}\right), 99.3\left(\mathrm{t},{ }^{2} J_{\mathrm{PC}}=25.3 \mathrm{~Hz}, \mathrm{C}_{\alpha}\right), 84.9(\mathrm{Cp})$, $38.3(\mathrm{CH}) .{ }^{31} \mathrm{P}$ NMR $\left(\mathrm{CDCl}_{3}\right): \delta 51.63,50.98$ (two d, ${ }^{2} J_{\mathrm{PP}}=37.0$ $\left.\mathrm{Hz}, \mathrm{PPh}_{3}\right)$. MS: $m / z$, $933.2\left(\mathrm{M}^{+}\right)$.

Preparation of $[\mathrm{Ru}] \mathrm{C} \equiv \mathbf{C C H}\left(\mathrm{C}_{14} \mathrm{H}_{9}\right) \mathrm{CH}_{2} \mathrm{CH}_{3}$ (5c). Complex 5c $(0.18 \mathrm{~g}, 90 \%$ yield $)$ was similarly prepared from $4 \mathbf{a}(0.22 \mathrm{~g}$, $0.21 \mathrm{mmol})$ and $\mathrm{CH}_{3} \mathrm{CH}_{2} \mathrm{MgBr}(1 \mathrm{~mL}, 2 \mathrm{M}$ in THF). Anal. Calcd for $\mathrm{C}_{60} \mathrm{H}_{50} \mathrm{P}_{2} \mathrm{Ru}$ : C, 77.15; H, 5.40. Found: C, 77.32; H, 5.51. ${ }^{1} \mathrm{H}$ NMR $\left(\mathrm{CDCl}_{3}\right): \delta 9.92(\mathrm{br}, 1 \mathrm{H}$, anthracene), $8.45(\mathrm{~m}, 2 \mathrm{H}$, anthracene), $8.06(\mathrm{~m}, 2 \mathrm{H}$, anthracene $), 7.64-6.67(\mathrm{~m}, 34 \mathrm{H}, \mathrm{Ph}$, anthracene), $5.32\left(\mathrm{t}, 1 \mathrm{H},{ }^{3} J_{\mathrm{HH}}=7.5 \mathrm{~Hz}, \mathrm{CH}\right), 4.30(\mathrm{~s}, 5 \mathrm{H}, \mathrm{Cp})$, $2.46\left(\mathrm{~m}, 1 \mathrm{H}, \mathrm{CH}_{2}\right), 1.96\left(\mathrm{~m}, 1 \mathrm{H}, \mathrm{CH}_{2}\right), 1.13\left(\mathrm{t}, 3 \mathrm{H},{ }^{3} J_{\mathrm{HH}}=7.3 \mathrm{~Hz}\right.$, $\left.\mathrm{CH}_{3}\right) \cdot{ }^{13} \mathrm{C}\left\{{ }^{1} \mathrm{H}\right\}$ NMR $\left(\mathrm{CDCl}_{3}\right): \delta$ 139.9-124.4 (s, Ph, anthracene), $112.9\left(\mathrm{C}_{\beta}\right), 95.4\left(\mathrm{t},{ }^{2} J_{\mathrm{PC}}=25.3 \mathrm{~Hz}, \mathrm{C}_{\alpha}\right), 84.9(\mathrm{Cp}), 37.1\left(\mathrm{CH}_{2}\right)$, $31.3(\mathrm{CH}), 13.7\left(\mathrm{CH}_{3}\right) .{ }^{31} \mathrm{P} \mathrm{NMR}\left(\mathrm{CDCl}_{3}\right): \delta 52.02,50.68($ two d, $\left.{ }^{2} J_{\mathrm{PP}}=37.4 \mathrm{~Hz}, \mathrm{PPh}_{3}\right)$. MS: $m / z, 934.06\left(\mathrm{M}^{+}\right)$.

Preparation of $[\mathrm{Ru}] \mathrm{C} \equiv \mathrm{CCH}\left(\mathrm{C}_{14} \mathrm{H}_{9}\right) \mathrm{CH}_{2} \mathrm{CH}_{2} \mathrm{CH}=\mathrm{CH}_{2}(5 \mathrm{e})$. Complex 5e $(0.19$ g, $82 \%$ yield $)$ was similarly prepared from $4 \mathbf{a}$ $(0.22 \mathrm{~g}, 0.21 \mathrm{mmol})$ and $\mathrm{CH}_{2}=\mathrm{CHCH}_{2} \mathrm{CH}_{2} \mathrm{MgBr}(4 \mathrm{~mL}, 0.5 \mathrm{M}$ in THF). Anal. Calcd for $\mathrm{C}_{62} \mathrm{H}_{52} \mathrm{P}_{2} \mathrm{Ru}$ : C, 77.56; H, 5.46. Found: $\mathrm{C}$, 77.42; H, 5.52. ${ }^{1} \mathrm{H} \mathrm{NMR}\left(\mathrm{CDCl}_{3}\right): \delta 8.38\left(\mathrm{~d}, 2 \mathrm{H},{ }^{3} J_{\mathrm{HH}}=5.2 \mathrm{~Hz}\right.$, anthracene $), 8.01(\mathrm{~m}, 3 \mathrm{H}$, anthracene $), 7.55-6.60(\mathrm{~m}, 34 \mathrm{H}, \mathrm{Ph}$, anthracene), $5.81(\mathrm{~m}, 1 \mathrm{H},=\mathrm{CH}), 5.38(\mathrm{~m}, 1 \mathrm{H}, \mathrm{CH}), 4.89(\mathrm{~d}, 1 \mathrm{H}$, ${ }^{3} J_{\mathrm{HH}}=11.2 \mathrm{~Hz}$, cis $\left.=\mathrm{CH}_{2}\right), 4.85\left(\mathrm{~d}, 1 \mathrm{H},{ }^{3} J_{\mathrm{HH}}=14.6 \mathrm{~Hz}\right.$, trans $\left.=\mathrm{CH}_{2}\right), 4.23(\mathrm{~s}, 5 \mathrm{H}, \mathrm{Cp}), 2.53\left(\mathrm{~m}, 2 \mathrm{H}, \mathrm{CH}_{2}\right), 2.21\left(\mathrm{~m}, 1 \mathrm{H}, \mathrm{CH}_{2}\right)$, $1.85\left(\mathrm{~m}, 1 \mathrm{H}, \mathrm{CH}_{2}\right) \cdot{ }^{13} \mathrm{C}\left\{{ }^{1} \mathrm{H}\right\} \mathrm{NMR}\left(\mathrm{CDCl}_{3}\right): \delta 139.8-123.3(\mathrm{~s}, \mathrm{Ph}$, anthracene, $=\mathrm{CH}), 114.3\left(C_{\beta}\right), 112.4\left(=\mathrm{CH}_{2}\right), 95.7\left(\mathrm{t},{ }^{2} J_{\mathrm{PC}}=25.3\right.$
$\left.\mathrm{Hz}, \mathrm{C}_{\alpha}\right), 84.8(\mathrm{Cp}), 37.0\left(\mathrm{CH}_{2}\right), 34.4\left(\mathrm{CH}_{2}\right), 32.8(\mathrm{CH}) .{ }^{31} \mathrm{P}$ NMR $\left(\mathrm{CDCl}_{3}\right): \delta 51.90,50.70\left(\right.$ two d, $\left.{ }^{2} J_{\mathrm{PP}}=37.3 \mathrm{~Hz}, \mathrm{PPh}_{3}\right) . \mathrm{MS}: \mathrm{m} / z$ $959.4\left(\mathrm{M}^{+}\right)$.

Preparation of $\left\{\left[\mathrm{Ru}^{\prime}\right]=\mathrm{C}=\mathrm{C}\left(\mathrm{CH}_{2} \mathrm{CH}=\mathrm{CH}_{2}\right) \mathrm{CH}(\mathbf{9}-\mathrm{Cl}-10\right.$ $\left.\left.\mathbf{C}_{14} \mathbf{H}_{8}\right) \mathbf{C H}_{2} \mathbf{C H}=\mathbf{C H}_{2}\right\}\left[\mathbf{I}_{3}\right]\left(6^{\prime}\right)$. To a Schlenk flask charged with complex $\mathbf{5}^{\prime}(0.10 \mathrm{~g}, 0.14 \mathrm{mmol})$ in $\mathrm{CH}_{2} \mathrm{Cl}_{2}(5 \mathrm{~mL})$ was added allyl iodide $(0.22 \mathrm{~mL}, 2.4 \mathrm{mmol})$ under nitrogen. The clear solution was stirred for $4 \mathrm{~h}$, and the color changed from yellow to deep red. Then the solution was filtered and the volume of the filtrate was reduced to $5 \mathrm{~mL}$ under vacuum. An aliquot of diethyl ether (50 $\mathrm{mL}$ ) was added to cause precipitation of a pink powder. After filtration, the precipitate was washed with $10 \mathrm{~mL}$ of diethyl ether twice and dried under vacuum to give the product 6' $(0.21 \mathrm{~g}, 78 \%$ yield). Anal. Calcd for $\mathrm{C}_{40} \mathrm{H}_{54} \mathrm{ClI}_{3} \mathrm{P}_{2} \mathrm{Ru}$ : C, 43.12; $\mathrm{H}, 4.89$ (contains a small amount of $\left.7^{\prime}\right) .{ }^{1} \mathrm{H}$ NMR $\left(\mathrm{CDCl}_{3}\right): \delta 8.85-7.47(\mathrm{~m}, 8 \mathrm{H}$, anthracene), $5.80(\mathrm{~m}, 1 \mathrm{H},=\mathrm{CH}), 5.70(\mathrm{~m}, 1 \mathrm{H}, \mathrm{CH}), 5.21(\mathrm{~s}, 5 \mathrm{H}$, $\mathrm{Cp}), 5.19(\mathrm{~m}, 1 \mathrm{H},=\mathrm{CH}), 5.11-4.92\left(\mathrm{~m}, 2 \mathrm{H},=\mathrm{CH}_{2}\right), 4.67-4.53$ $\left(\mathrm{m}, 2 \mathrm{H},=\mathrm{CH}_{2}\right), 3.24-2.70\left(\mathrm{~m}, 4 \mathrm{H}, \mathrm{CH}_{2}\right), 1.95-1.24(\mathrm{~m}, 12 \mathrm{H}$, $\left.\mathrm{CH}_{2}\right), 1.13-0.74\left(\mathrm{~m}, 18 \mathrm{H}, \mathrm{CH}_{3}\right) .{ }^{31} \mathrm{P} \mathrm{NMR}\left(\mathrm{CDCl}_{3}\right): \delta 36.28,35.16$ $\left(2 \mathrm{~d},{ }^{2} J_{\mathrm{PP}}=33.9 \mathrm{~Hz}, \mathrm{PEt}_{3}\right)$. MS: $m / z 733.3\left(\mathrm{M}^{+}\right)$.

Preparation of Complex 6". Compound 6" (0.18 g, 92\%) was prepared similarly from the reaction of $\mathbf{5}^{\prime}(0.14 \mathrm{~g}, 0.23 \mathrm{mmol})$ and 3-chloro-2-methyl-1-propene $(0.3 \mathrm{~mL}, 2.74 \mathrm{mmol})$ at room temperature in $\mathrm{CH}_{2} \mathrm{Cl}_{2}$. Anal. Calcd for $\mathrm{C}_{41} \mathrm{H}_{56} \mathrm{ClI}_{3} \mathrm{P}_{2} \mathrm{Ru}$ : C, 43.65; $\mathrm{H}$, 5.00 (contains a small amount of $\left.7^{\prime \prime}\right) .{ }^{1} \mathrm{H}$ NMR $\left(\mathrm{CDCl}_{3}\right): \delta$ $8.76-7.54\left(\mathrm{~m}, 8 \mathrm{H}\right.$, anthracene), $5.85\left(\mathrm{~d},{ }^{3} J_{\mathrm{HH}}=8.2 \mathrm{~Hz}, 1 \mathrm{H}, \mathrm{CH}-\right.$ antracene), 5.05 (broad s, $\left.1 \mathrm{H},=\mathrm{CH}_{2}\right), 5.03\left(\right.$ broad s, $1 \mathrm{H},=\mathrm{CH}_{2}$ ), $5.00(\mathrm{~s}, 5 \mathrm{H}, \mathrm{Cp}), 5.20(\mathrm{~m}, 1 \mathrm{H},=\mathrm{CH}), 4.66\left(\mathrm{~d},{ }^{3} J_{\mathrm{HH}}=16.9 \mathrm{~Hz}\right.$, $1 \mathrm{H}$, trans $\left.=\mathrm{CH}_{2}\right), 4.56\left(\mathrm{~d},{ }^{3} J_{\mathrm{HH}}=9.9 \mathrm{~Hz}, 1 \mathrm{H}\right.$, cis $\left.=\mathrm{CH}_{2}\right), 3.27(\mathrm{~d}$, $\left.{ }^{2} J_{\mathrm{HH}}=18.0 \mathrm{~Hz}, 1 \mathrm{H}, \mathrm{CH}_{2}\right), 2.81\left(\mathrm{~d},{ }^{2} J_{\mathrm{HH}}=18.0 \mathrm{~Hz}, 1 \mathrm{H}, \mathrm{CH}_{2}\right)$, $2.99\left(\mathrm{~m}, 1 \mathrm{H}, \mathrm{CH}_{2}\right), 2.75\left(\mathrm{~m}, 1 \mathrm{H}, \mathrm{CH}_{2}\right), 1.71\left(\mathrm{~s}, 3 \mathrm{H}, \mathrm{CH}_{3}\right), 1.87-1.64$ $\left(\mathrm{m}, 6 \mathrm{H}, \mathrm{PCH}_{2}\right), 1.43-1.10\left(\mathrm{~m}, 12 \mathrm{H}, \mathrm{PCH}_{2}\right), 1.07-0.99(\mathrm{~m}, 9 \mathrm{H}$, $\left.\mathrm{CH}_{3}\right), 0.75-0.67\left(\mathrm{~m}, 9 \mathrm{H}, \mathrm{CH}_{3}\right) \cdot{ }^{31} \mathrm{C} \mathrm{NMR}\left(\mathrm{CDCl}_{3}\right): \delta 348.0(\mathrm{t}$, $\left.{ }^{2} J_{\mathrm{CP}}=13.7 \mathrm{~Hz}, \mathrm{C}_{\alpha}\right), 143.6-124.7$ (anthracene), $135.1(=\mathrm{CH}), 134.7$ $(=\mathrm{C}(\mathrm{Me})), 123.0\left(\mathrm{C}_{\beta}\right), 116.9\left(=\mathrm{CH}_{2}\right), 111.7\left(=\mathrm{CH}_{2}\right), 89.2(\mathrm{Cp})$, 53.4 (C-anthracene), $38.1\left(\mathrm{CH}_{2}\right), 32.9\left(\mathrm{CH}_{2}\right), 30.9\left(\mathrm{CH}_{3}\right) .{ }^{31} \mathrm{P}$ NMR $\left(\mathrm{CDCl}_{3}\right): \delta 36.36,34.96\left(\right.$ two d, $\left.{ }^{2} J_{\mathrm{PP}}=33.6 \mathrm{~Hz}, \mathrm{PEt}_{3}\right) . \mathrm{MS}: \mathrm{m} / \mathrm{z}$ $747.3\left(\mathrm{M}^{+}\right)$.

Preparation of $\left\{[\mathrm{Ru}]=\mathrm{C}=\mathrm{C}\left(\mathrm{CH}_{2} \mathrm{CH}=\mathrm{CH}_{2}\right) \mathrm{CH}\left(\mathrm{C}_{14} \mathrm{H}_{9}\right) \mathrm{CH}_{2}\right.$ $\left.\mathbf{C H}_{3}\right\}\left[\mathbf{I}_{3}\right](\mathbf{6 c})$. Complex 5c $(0.09 \mathrm{~g}, 0.10 \mathrm{mmol})$ and $\mathrm{CH}_{2} \mathrm{Cl}_{2}(10$ $\mathrm{mL}$ ) were added in a Schlenk flask under nitrogen. To the resulting solution was added allyl iodide $(0.05 \mathrm{~mL}, 0.53 \mathrm{mmol})$, and this mixture was stirred for $8 \mathrm{~h}$ at room temperature. The solvent was removed in vacuo, and $\mathrm{CH}_{2} \mathrm{Cl}_{2}(2 \times 5 \mathrm{~mL})$ was used to extract the product. The resulting solution was concentrated to ca. $5 \mathrm{~mL}$ and added to stirred diethyl ether $(60 \mathrm{~mL})$ to produce a red precipitate, which was filtered, washed with diethyl ether, and identified as $\mathbf{6 c}$ (0.10 g, 92\% yield). Anal. Calcd for $\mathrm{C}_{63} \mathrm{H}_{55} \mathrm{I}_{3} \mathrm{P}_{2} \mathrm{Ru}$ : C, 55.81; $\mathrm{H}$, 4.09. Found: C, 56.01; $\mathrm{H}, 4.15 .{ }^{1} \mathrm{H} \mathrm{NMR}\left(\mathrm{CDCl}_{3}\right): \delta 9.19(\mathrm{~d}, 1 \mathrm{H}$, ${ }^{3} J_{\mathrm{HH}}=8.6 \mathrm{~Hz}$, anthracene), $8.49(\mathrm{~s}, 1 \mathrm{H}$, anthracene $), 8.15(\mathrm{~d}, 1 \mathrm{H}$, ${ }^{3} J_{\mathrm{HH}}=8.5 \mathrm{~Hz}$, anthracene $), 8.06\left(\mathrm{~d}, 1 \mathrm{H},{ }^{3 \mathrm{~J}} \mathrm{HH}=11.1 \mathrm{~Hz}\right.$, anthracene), 8.04 (d, $1 \mathrm{H},{ }^{3} \mathrm{~J}_{\mathrm{HH}}=9.8 \mathrm{~Hz}$, anthracene), 7.83-6.80 (m, 34H, Ph, anthracene), 5.45 (br d, $\left.1 \mathrm{H},{ }^{3} J_{\mathrm{HH}}=10.7 \mathrm{~Hz}, \mathrm{CH}\right)$, $5.22(\mathrm{~m}, 1 \mathrm{H},=\mathrm{CH}), 5.05(\mathrm{~s}, 5 \mathrm{H}, \mathrm{Cp}), 4.72\left(\mathrm{~d}, 1 \mathrm{H},{ }^{3} J_{\mathrm{HH}}=10.7\right.$ $\mathrm{Hz}$, cis $\left.=\mathrm{CH}_{2}\right), 4.12\left(\mathrm{~d}, 1 \mathrm{H},{ }^{3} \mathrm{~J}_{\mathrm{HH}}=16.9 \mathrm{~Hz}\right.$, trans $\left.=\mathrm{CH}_{2}\right)$, $2.51-2.13\left(\mathrm{~m}, 4 \mathrm{H}, \mathrm{CH}_{2}\right), 1.21\left(\mathrm{t}, 3 \mathrm{H},{ }^{3} \mathrm{~J}_{\mathrm{HH}}=7.1 \mathrm{~Hz}, \mathrm{CH}_{3}\right) .{ }^{13} \mathrm{C}\left\{{ }^{1} \mathrm{H}\right\}$ NMR $\left(\mathrm{CDCl}_{3}\right): \delta 356.3\left(\mathrm{t},{ }^{2} J_{\mathrm{PC}}=14.7 \mathrm{~Hz}, \mathrm{C}_{\alpha}\right), 145.73-120.4$ $\left(=\mathrm{CH}, \mathrm{Ph}\right.$, anthracene, $\left.\mathrm{C}_{\beta}\right), 118.4\left(=\mathrm{CH}_{2}\right), 93.5(\mathrm{Cp}), 37.8\left(\mathrm{CH}_{2}\right)$, 29.3 $\left(\mathrm{CH}_{2}\right), 28.51(\mathrm{CH}), 12.8\left(\mathrm{CH}_{3}\right) .{ }^{31} \mathrm{P}\left\{{ }^{1} \mathrm{H}\right\}$ NMR $\left(\mathrm{CDCl}_{3}\right): \delta$ 41.17, 39.22 (2 d, $\left.{ }^{2} J_{\mathrm{PP}}=27.6 \mathrm{~Hz}, \mathrm{PPh}_{3}\right)$. MS: $m / z 975.3\left(\mathrm{M}^{+}\right)$.

Preparation of Complex 7. Complex 5 (0.20 g, $0.21 \mathrm{mmol})$ was added into a Schlenk flask, and $\mathrm{CH}_{2} \mathrm{Cl}_{2}(10 \mathrm{~mL})$ was then added under nitrogen. To the resulting solution was added allyl iodide $(0.10 \mathrm{~mL}, 1.06 \mathrm{mmol})$, and the mixture was stirred for 3 days at room temperature. The solvent was removed in vacuo, and $\mathrm{CH}_{2} \mathrm{Cl}_{2}$ $(2 \times 5 \mathrm{~mL})$ was used to extract the product. The resulting solution was concentrated to ca. $5 \mathrm{~mL}$ and added to stirred diethyl ether 
$(60 \mathrm{~mL})$ to produce a yellow precipitate. The powder was filtered, washed with diethyl ether, and dried under vacuum to give 7 (0.22 g, $93 \%$ yield). Anal. Calcd for $\mathrm{C}_{64} \mathrm{H}_{54} \mathrm{ClI}_{3} \mathrm{P}_{2} \mathrm{Ru}$ : C, 54.82; $\mathrm{H}, 3.88$. Found: C, 54.91; $\mathrm{H}, 3.95 .{ }^{1} \mathrm{H} \mathrm{NMR}\left(\mathrm{CDCl}_{3}\right): \delta 7.85-7.04(\mathrm{~m}, 38 \mathrm{H}$, $\mathrm{Ph}), 5.72(\mathrm{~m}, 1 \mathrm{H},=\mathrm{CH}), 5.27(\mathrm{~s}, 5 \mathrm{H}, \mathrm{Cp}), 5.11\left(\mathrm{~m}, 2 \mathrm{H},=\mathrm{CH}_{2}\right)$, 4.28 (br s, $1 \mathrm{H}, \mathrm{CH}), 3.42\left(\mathrm{~m}, 1 \mathrm{H}, \mathrm{CH}_{2}\right), 3.19\left(\mathrm{~m}, 1 \mathrm{H}, \mathrm{CH}_{2}\right), 2.48$ $\left(\mathrm{m}, 1 \mathrm{H}, \mathrm{CH}_{2}\right), 2.17\left(\mathrm{~m}, 1 \mathrm{H}, \mathrm{CH}_{2}\right), 1.82\left(\mathrm{~m}, 1 \mathrm{H}, \mathrm{CH}_{2}\right), 1.76(\mathrm{~m}$, $1 \mathrm{H}, \mathrm{CH}), 1.46\left(\mathrm{~m}, 1 \mathrm{H}, \mathrm{CH}_{2}\right) \cdot{ }^{13} \mathrm{C} \mathrm{NMR}\left(\mathrm{CDCl}_{3}\right): \delta 354.6\left(\mathrm{t},{ }^{2} J_{\mathrm{PC}}\right.$ $\left.=15.6 \mathrm{~Hz}, \mathrm{C}_{\alpha}\right), 144.08-121.1(\mathrm{Ph}) 137.7(=\mathrm{CH}), 129.8\left(\mathrm{~s}, \mathrm{C}_{\beta}\right)$, $117.1\left(=\mathrm{CH}_{2}\right), 93.7(\mathrm{~s}, \mathrm{Cp}), 71.3(\mathrm{~s}, \mathrm{CCl}), 58.3(\mathrm{~s}, \mathrm{C}($ bridgehead $))$, $47.3(\mathrm{~s}, \mathrm{CH}), 44.4(\mathrm{~s}, \mathrm{CH}), 43.8\left(\mathrm{~s}, \mathrm{CH}_{2}\right), 36.4\left(\mathrm{~s}, \mathrm{CH}_{2}\right), 31.9(\mathrm{~s}$, $\left.\mathrm{CH}_{2}\right) .{ }^{31} \mathrm{P}$ NMR $\left(\mathrm{CDCl}_{3}\right): \delta 42.88,40.34\left(2 \mathrm{~d},{ }^{2} J_{\mathrm{PP}}=27.5 \mathrm{~Hz}\right)$. MS: $m / z, 1021.4\left(\mathrm{M}^{+}\right)$.

Preparation of Complex 7'. To a Schlenk flask charged with complex 6' $(0.10 \mathrm{~g}, 0.090 \mathrm{mmol})$ was added $\mathrm{CH}_{2} \mathrm{Cl}_{2}(5 \mathrm{~mL})$ under nitrogen. The clear solution was stirred at $40{ }^{\circ} \mathrm{C}$ for 5 days. The solution was filtered, and the volume of the filtrate was reduced to $2 \mathrm{~mL}$ under vacuum. Then $50 \mathrm{~mL}$ of diethyl ether was added to cause precipitation of an orange powder. After filtration, the precipitate was washed with $10 \mathrm{~mL}$ of diethyl ether twice and dried under vacuum to give the product $7^{\prime}$ ( $0.08 \mathrm{~g}, 80 \%$ yield). Anal. Calcd for $\mathrm{C}_{40} \mathrm{H}_{54} \mathrm{ClI}_{3} \mathrm{P}_{2} \mathrm{Ru}$ : C, 43.12; H, 4.89. Found: C, 43.26; $\mathrm{H}$, 4.97. ${ }^{1} \mathrm{H}$ NMR $\left(\mathrm{CDCl}_{3}\right): \delta 7.78-7.16(\mathrm{~m}, 8 \mathrm{H}, \mathrm{Ph}), 6.04(\mathrm{~m}, 1 \mathrm{H}$, $=\mathrm{CH}), 5.55(\mathrm{~s}, 5 \mathrm{H}, \mathrm{Cp}), 5.32-5.28\left(\mathrm{~m}, 2 \mathrm{H},=\mathrm{CH}_{2}\right), 4.30$ (broad singlet, $1 \mathrm{H}, \mathrm{CH}), 3.36-3.05\left(\mathrm{~m}, 2 \mathrm{H}, \mathrm{CH}_{2}\right), 3.10-3.05(\mathrm{~m}, 1 \mathrm{H}$, $\left.\mathrm{CH}_{2}\right), 2.33-2.24\left(\mathrm{~m}, 2 \mathrm{H}, \mathrm{CH}_{2}\right), 2.00-1.72\left(\mathrm{~m}, 12 \mathrm{H}, \mathrm{CH}_{2}\right), 1.94$ $(\mathrm{m}, 1 \mathrm{H}, \mathrm{CH}), 1.72(\mathrm{~m}, 1 \mathrm{H}, \mathrm{CH}), 1.22-1.03\left(\mathrm{~m}, 18 \mathrm{H}, \mathrm{CH}_{3}\right) .{ }^{13} \mathrm{C}$ NMR $\left(\mathrm{CDCl}_{3}\right): \delta 346.9\left(\mathrm{t},{ }^{2} J_{\mathrm{PP}}=14.2 \mathrm{~Hz}, \mathrm{C}_{\alpha}\right), 127.8\left(\mathrm{C}_{\beta}\right)$, 144.3-120.9 $(\mathrm{Ph}), 137.1(=\mathrm{CH}), 116.8\left(=\mathrm{CH}_{2}\right), 89.7(\mathrm{Cp}), 71.3$ $(\mathrm{C}-\mathrm{Cl}), 58.3\left(\mathrm{C}(\right.$ bridge head) $), 46.8(\mathrm{CH}), 42.9(\mathrm{CH}), 43.9\left(\mathrm{CH}_{2}\right)$, $35.3\left(\mathrm{CH}_{2}\right), 32.7\left(\mathrm{CH}_{2}\right), 23.5-23.2\left(\mathrm{PEt}_{3}\right), 8.8-8.7\left(\mathrm{PEt}_{3}\right){ }^{31} \mathrm{P} \mathrm{NMR}$ $\left(\mathrm{CDCl}_{3}\right): \delta 38.13,37.48\left(2 \mathrm{~d},{ }^{2} J_{\mathrm{PP}}=33.6 \mathrm{~Hz}, \mathrm{PEt}_{3}\right) . \mathrm{MS}: \mathrm{m} / \mathrm{z} 733.3$ $\left(\mathrm{M}^{+}\right)$.

Preparation of Complex 7". To a Schlenk flask charged with complex 6" $(0.21 \mathrm{~g}, 0.23 \mathrm{mmol})$ was added $\mathrm{CHCl}_{3}(10 \mathrm{~mL})$ under nitrogen. The clear solution was heated to reflux for 2 days. Then the solution was filtered and the volume of the filtrate was reduced to $2 \mathrm{~mL}$ under vacuum. An aliquot of petroleum ether $(50 \mathrm{~mL})$ was added to cause precipitation of an orange powder. After filtration, the precipitate was washed with $10 \mathrm{~mL}$ of petroleum ether twice and dried under vacuum to give the product $7^{\prime \prime}(0.17 \mathrm{~g}, 82 \%$ yield). Anal. Calcd for $\mathrm{C}_{41} \mathrm{H}_{56} \mathrm{ClI}_{3} \mathrm{P}_{2} \mathrm{Ru}$ : C, 43.65; H, 5.00. Found: $\mathrm{C}, 43.79 ; \mathrm{H}, 5.21 .{ }^{1} \mathrm{H}$ NMR $\left(\mathrm{CDCl}_{3}\right): \delta 7.76-7.18(\mathrm{~m}, 8 \mathrm{H}, \mathrm{Ph})$, $6.05(\mathrm{~m}, 1 \mathrm{H},=\mathrm{CH}), 5.49(\mathrm{~s}, 5 \mathrm{H}, \mathrm{Cp}), 5.28\left(\mathrm{~d},{ }^{3} J_{\mathrm{HH}}=17.3 \mathrm{~Hz}\right.$, $1 \mathrm{H}$, trans $\left.=\mathrm{CH}_{2}\right), 5.29\left(\mathrm{~d},{ }^{3} \mathrm{~J}_{\mathrm{HH}}=9.6 \mathrm{~Hz}, 1 \mathrm{H}\right.$, cis $\left.=\mathrm{CH}_{2}\right), 4.47$ (br. s, $1 \mathrm{H}, \mathrm{CH}$ ), 3.30, $3.10\left(\mathrm{~m}, 2 \mathrm{H}, \mathrm{CH}_{2}\right.$ ), 2.71, 2.53 (two d, ${ }^{2} J_{\mathrm{HH}}$ $\left.=13.8 \mathrm{~Hz}, 2 \mathrm{H}, \mathrm{CH}_{2}\right), 2.12,1.88\left(\right.$ two d, $\left.{ }^{2} J_{\mathrm{HH}}=11.9 \mathrm{~Hz}, 2 \mathrm{H}, \mathrm{CH}_{2}\right)$, 2.05-1.65 (m, 15H, $\left.\mathrm{PEt}_{3}, \mathrm{CH}_{3}\right), 1.22-1.05\left(\mathrm{~m}, \mathrm{PEt}_{3}\right) .{ }^{13} \mathrm{C} \mathrm{NMR}$ $\left(\mathrm{CDCl}_{3}\right): \delta 346.3\left(\mathrm{t},{ }^{2} J_{\mathrm{PP}}=14.8 \mathrm{~Hz}, \mathrm{C}_{\alpha}\right), 126.9\left(\mathrm{C}_{\beta}\right), 140.2-121.0$ $(\mathrm{Ph}), 138.5(=\mathrm{CH}), 116.8\left(=\mathrm{CH}_{2}\right), 89.5(\mathrm{Cp}), 71.3(\mathrm{C}-\mathrm{Cl}), 61.5$ (C(bridgehead)), $53.2\left(\mathrm{C}\left(\mathrm{CH}_{3}\right)\right), 40.6(\mathrm{CH}), 47.9\left(\mathrm{CH}_{2}\right), 39.5\left(\mathrm{CH}_{2}\right)$, $35.8\left(\mathrm{CH}_{2}\right), 23.2-22.4\left(\mathrm{PEt}_{3}, \mathrm{CH}_{3}\right), 8.49-8.45\left(\mathrm{PEt}_{3}\right) .{ }^{31} \mathrm{P} \mathrm{NMR}$ $\left(\mathrm{CDCl}_{3}\right): \delta 38.08,37.62$ (two d, ${ }^{2} J_{\mathrm{PP}}=33.8 \mathrm{~Hz}, \mathrm{PEt}_{3}$ ). MS: $\mathrm{m} / z$ $747.3\left(\mathrm{M}^{+}\right)$.

Preparation of Complex 7a. Complex 5a (0.10 g, $0.11 \mathrm{mmol})$ and $\mathrm{KPF}_{6}(0.06 \mathrm{~g}, 0.34 \mathrm{mmol})$ were added into a Schlenk flask, and $\mathrm{CH}_{2} \mathrm{Cl}_{2}(10 \mathrm{~mL})$ was then added under nitrogen. To the resulting solution was added allyl iodide $(0.05 \mathrm{~mL}, 0.53 \mathrm{mmol})$, and this mixture was stirred for $12 \mathrm{~h}$ at room temperature. The solvent was removed in vacuo, and $\mathrm{CH}_{2} \mathrm{Cl}_{2}(2 \times 5 \mathrm{~mL})$ was used to extract the product. The resulting solution was concentrated to ca. $5 \mathrm{~mL}$ and added to stirred diethyl ether $(60 \mathrm{~mL})$ to produce a dark yellow precipitate. The powder was filtered, washed with diethyl ether, and identified as $7 \mathbf{a}(0.11 \mathrm{~g}, 89 \%$ yield $)$. Anal. Calcd for $\mathrm{C}_{63} \mathrm{H}_{51} \mathrm{I}_{3} \mathrm{P}_{2} \mathrm{Ru}$ : C, 55.97; $\mathrm{H}, 3.80$. Found: $\mathrm{C}, 55.93 ; \mathrm{H}, 3.84 .{ }^{1} \mathrm{H}$ NMR $\left(\mathrm{CDCl}_{3}\right): \delta 8.47\left(\mathrm{~d}, 1 \mathrm{H},{ }^{3} \mathrm{~J}_{\mathrm{HH}}=8 \mathrm{~Hz}, \mathrm{Ph}\right), 7.36-6.94(\mathrm{~m}$, $37 \mathrm{H}, \mathrm{Ph}$ ), 5.27 (s, 5H, Cp), 4.72 (br s, $1 \mathrm{H}, \mathrm{CH}$ ), 4.29 (br s, $1 \mathrm{H}$,
Table 1. Crystal Data and Refinement Parameters for Complexes $7 \mathrm{~b}$ and $7 \mathrm{c}$

\begin{tabular}{lll}
\hline & \multicolumn{1}{c}{$\mathbf{7 b}$} & \multicolumn{1}{c}{$\mathbf{7 c}$} \\
\hline formula & $\mathrm{C}_{63} \mathrm{H}_{53} \mathrm{I}_{3} \mathrm{P}_{2} \mathrm{Ru}$ & $\mathrm{C}_{63} \mathrm{H}_{55} \mathrm{I}_{3} \mathrm{P}_{2} \mathrm{Ru}$ \\
mass (amu) & 1353.76 & 1355.78 \\
space group & $P 2_{1} / n$ & $P 2_{1} / n$ \\
$a(\AA)$ & $16.7766(3)$ & $16.8783(3)$ \\
$b(\AA)$ & $15.2633(2)$ & $15.2258(3)$ \\
$c(\AA)$ & $21.3190(4)$ & $21.2754(5)$ \\
$\beta(\mathrm{deg})$ & $96.402(1)$ & $96.934(2)$ \\
$V\left(\AA^{3}\right) ; Z$ & $5425.03(16) ; 4$ & $5427.50(2) ; 4$ \\
$\theta_{\text {max }}(\mathrm{deg})$ & 27.5 & 27.5 \\
abs coeff, $\mu(\mathrm{Mo} \mathrm{K} \alpha)\left(\mathrm{mm}^{-1}\right)$ & 2.095 & 2.094 \\
no. of indep rflns; $R_{\text {int }}$ & $12385 ; 0.0499$ & $12421 ; 0.0979$ \\
no. of params & 622 & 622 \\
$\mathrm{R} 1$ for $I>2 \sigma(I)$ & 0.0489 & 0.0439 \\
wR2, all data & 0.1211 & 0.0799 \\
goodness of fit on $F^{2}$ & 0.945 & 0.830
\end{tabular}

$\mathrm{CH}), 2.73\left(\mathrm{~d}, 1 \mathrm{H},{ }^{3} J_{\mathrm{HH}}=3 \mathrm{~Hz}, \equiv \mathrm{CH}\right), 2,55\left(\mathrm{~m}, 1 \mathrm{H}, \mathrm{CH}_{2}\right), 1.93$ $\left(\mathrm{m}, 2 \mathrm{H}, \mathrm{CH}_{2}\right), 1.46(\mathrm{~m}, 1 \mathrm{H}, \mathrm{CH}), 1.15\left(\mathrm{~m}, 1 \mathrm{H}, \mathrm{CH}_{2}\right) \cdot{ }^{13} \mathrm{C}\left\{{ }^{1} \mathrm{H}\right\} \mathrm{NMR}$ $\left(\mathrm{CDCl}_{3}\right): \delta 353.8,353.7\left(2 \mathrm{~d},{ }^{2} J_{\mathrm{PC}}=13.6 \mathrm{~Hz}, \mathrm{C}_{\alpha}\right), 145.1-120.2$ ( $\mathrm{Ph}$, anthracene, $\left.\mathrm{C}_{\beta}\right), 93.9(\mathrm{~s}, \mathrm{Cp}), 83.8(\mathrm{~s}, \equiv \mathrm{C}), 75.7$ (,$\left.\equiv \mathrm{CH}\right)$, 57.4 (s, C(bridgehead)), 45.3 (s, $\mathrm{CH}$ (bridgehead)), 45.2 (s, $\mathrm{CH}$ ), $32.8(\mathrm{~s}, \mathrm{CH}), 32.7\left(\mathrm{~s}, \mathrm{CH}_{2}\right), 31.9\left(\mathrm{~s}, \mathrm{CH}_{2}\right) .{ }^{31} \mathrm{P}\left\{{ }^{1} \mathrm{H}\right\} \mathrm{NMR}\left(\mathrm{CDCl}_{3}\right)$ : $\delta$ 43.01; $41.64\left(2 \mathrm{~d},{ }^{2} J_{\mathrm{PP}}=27.18 \mathrm{~Hz}\right)$. MS: $m / z$ 971.2 $\left(\mathrm{M}^{+}\right)$.

Preparation of Complex 7b. To a Schlenk flask containing $\mathbf{5 b}$ $(0.10 \mathrm{~g}, 0.11 \mathrm{mmol})$ was added $\mathrm{CH}_{2} \mathrm{Cl}_{2}(10 \mathrm{~mL})$ under nitrogen. To the resulting solution was added allyl iodide $(0.05 \mathrm{~mL}, 0.53$ $\mathrm{mmol}$ ), and this mixture was stirred for 3 days at room temperature. The solvent was removed in vacuo, and $\mathrm{CH}_{2} \mathrm{Cl}_{2}(2 \times 5 \mathrm{~mL})$ was used to extract the product. The resulting solution was concentrated to ca. $5 \mathrm{~mL}$ and added to stirred diethyl ether $(60 \mathrm{~mL})$ to produce a red precipitate. The powder was filtered, washed with diethyl ether, and identified as $7 \mathbf{b}(0.10 \mathrm{~g}, 83 \%$ yield). Anal. Calcd for $\mathrm{C}_{63} \mathrm{H}_{53} \mathrm{I}_{3} \mathrm{P}_{2} \mathrm{Ru}$ : C, 55.89; H, 3.95. Found: C, 55.93; H, 4.01. ${ }^{1} \mathrm{H}$ NMR $\left(\mathrm{CDCl}_{3}\right): \delta 7.99\left(\mathrm{~d}, 1 \mathrm{H},{ }^{3} J_{\mathrm{HH}}=7.2 \mathrm{~Hz}\right.$, anthracene), $7.43-6.83$ $(\mathrm{m}, 37 \mathrm{H}, \mathrm{Ph}$, anthracene $), 6.02(\mathrm{~m}, 1 \mathrm{H},=\mathrm{CH}), 5.47\left(\mathrm{~d}, 1 \mathrm{H},{ }^{3} \mathrm{~J}_{\mathrm{HH}}\right.$ $=10.4 \mathrm{~Hz}$, cis $\left.=\mathrm{CH}_{2}\right), 5.42\left(\mathrm{~d}, 1 \mathrm{H},{ }^{3} \mathrm{~J}_{\mathrm{HH}}=17.2 \mathrm{~Hz}\right.$, trans $\left.=\mathrm{CH}_{2}\right)$, $5.21(\mathrm{~s}, 5 \mathrm{H}, \mathrm{Cp}), 4.87$ (br d, $\left.1 \mathrm{H},{ }^{3} \mathrm{~J}_{\mathrm{HH}}=8.2 \mathrm{~Hz}, \mathrm{CH}\right), 4.25$ (br s, $1 \mathrm{H}, \mathrm{CH}), 2,53\left(\mathrm{~m}, 1 \mathrm{H}, \mathrm{CH}_{2}\right), 1.85\left(\mathrm{~m}, 2 \mathrm{H}, \mathrm{CH}_{2}\right), 1.57(\mathrm{~m}, 1 \mathrm{H}$, $\mathrm{CH}), 1.04\left(\mathrm{~m}, 1 \mathrm{H}, \mathrm{CH}_{2}\right) \cdot{ }^{13} \mathrm{C} \mathrm{NMR}\left(\mathrm{CDCl}_{3}\right): \delta 353.4\left(\mathrm{t},{ }^{2} J_{\mathrm{PC}}=\right.$ $\left.16.5 \mathrm{~Hz}, \mathrm{C}_{\alpha}\right), 155.1-120.9\left(\mathrm{Ph}\right.$, anthracene, $\left.\mathrm{CH}=\mathrm{CH}_{2}, \mathrm{C}_{\beta}\right), 93.6$ (Cp), 56.9 (C(bridgehead)), $49.7(\mathrm{CH}), 46.5$ (CH(bridgehead)), 45.6 (CH), $32.5\left(\mathrm{CH}_{2}\right), 31.3\left(\mathrm{CH}_{2}\right) .{ }^{31} \mathrm{P}$ NMR $\left(\mathrm{CDCl}_{3}\right): \delta 43.29,40.90$ $\left(2 \mathrm{~d},{ }^{2} J_{\mathrm{PP}}=27.7 \mathrm{~Hz}\right)$. MS: $m / z, 973.2\left(\mathrm{M}^{+}\right)$.

Preparation of Complex 7c. A solution of complex $6 \mathbf{c}(0.10 \mathrm{~g}$, $0.07 \mathrm{mmol})$ in $\mathrm{CH}_{2} \mathrm{Cl}_{2}(15 \mathrm{~mL})$ was heated to $40{ }^{\circ} \mathrm{C}$ for 6 days. Then the solution was concentrated to ca. $3 \mathrm{~mL}$ and added to stirred diethyl ether $(40 \mathrm{~mL})$ to produce a red precipitate. The powder was filtered and washed with diethyl ether, to give the product $7 \mathbf{c}$ (0.09 g, 87\% yield). Anal. Calcd for $\mathrm{C}_{63} \mathrm{H}_{55} \mathrm{I}_{3} \mathrm{P}_{2} \mathrm{Ru}$ : C, 55.81; $\mathrm{H}$, 4.09. Found: C, 55.91; $\mathrm{H}, 4.24 .{ }^{1} \mathrm{H} \mathrm{NMR}\left(\mathrm{CDCl}_{3}\right): \delta 7.87(\mathrm{~d}, 1 \mathrm{H}$, $\left.{ }^{3} J_{\mathrm{HH}}=7.5 \mathrm{~Hz}, \mathrm{Ph}\right), 7.52-6.78(\mathrm{~m}, 37 \mathrm{H}, \mathrm{Ph}), 5.26(\mathrm{~s}, 5 \mathrm{H}, \mathrm{Cp})$, 4.24 (br s, $1 \mathrm{H}, \mathrm{CH}$ ), 4.12 (br s, $1 \mathrm{H}, \mathrm{CH}), 2.73\left(\mathrm{~m}, 1 \mathrm{H}, \mathrm{CH}_{2}\right.$ ), 2.49-2.37 (m, $\left.2 \mathrm{H}, \mathrm{CH}_{2}, \mathrm{CH}_{2}\right), 1.86-1.62\left(\mathrm{~m}, 3 \mathrm{H}, \mathrm{CH}_{2}, \mathrm{CH}, \mathrm{CH}_{2}\right)$, $1.19\left(\mathrm{t}, 3 \mathrm{H},{ }^{3} \mathrm{~J}_{\mathrm{HH}}=7.1 \mathrm{~Hz}, \mathrm{CH}_{3}\right), 0.97\left(\mathrm{~m}, 1 \mathrm{H}, \mathrm{CH}_{2}\right) .{ }^{13} \mathrm{C} \mathrm{NMR}$ $\left(\mathrm{CDCl}_{3}\right): \delta 354.4\left(\mathrm{t},{ }^{2} J_{\mathrm{PC}}=15.2 \mathrm{~Hz}, \mathrm{C}_{\alpha}\right), 145.7-123.3(\mathrm{Ph}$, anthracene), $120.4\left(\mathrm{C}_{\beta}\right), 93.6(\mathrm{Cp}), 59.3$ (C(bridgehead)), $48.5(\mathrm{CH})$, $46.3\left(\mathrm{CH}\right.$ (bridgehead)), $45.7(\mathrm{CH}), 32.8\left(\mathrm{CH}_{2}\right), 32.3\left(\mathrm{CH}_{2}\right), 26.1$ $\left(\mathrm{CH}_{2}\right), 16.6\left(\mathrm{CH}_{3}\right) .{ }^{31} \mathrm{P} \mathrm{NMR}\left(\mathrm{CDCl}_{3}\right): \delta 43.11,41.80\left(2 \mathrm{~d},{ }^{2} J_{\mathrm{PP}}=\right.$ $27.5 \mathrm{~Hz})$. MS: $m / z, 975.3\left(\mathrm{M}^{+}\right)$.

Preparation of Complex 7e. Allyl bromide was dried by washing with saturated $\mathrm{NaHCO}_{3}$ aqueous solution and then was fractionally distilled from anhydrous $\mathrm{MgSO}_{4}$. The dried reagent should be protected from strong light. To a Schlenk flask containing complex 5e (0.12 g, $0.12 \mathrm{mmol}), \mathrm{KPF}_{6}(0.06 \mathrm{~g}, 0.34 \mathrm{mmol})$, and $\mathrm{CH}_{2} \mathrm{Cl}_{2}(10 \mathrm{~mL})$ was added dried allyl bromide $(0.10 \mathrm{~mL}, 0.60$ $\mathrm{mmol}$ ), and the mixture was stirred for $8 \mathrm{~h}$ at room temperature. Then the solvent was removed in vacuo, and $\mathrm{CH}_{2} \mathrm{Cl}_{2}(2 \times 5 \mathrm{~mL})$ 
was used to extract the product. The resulting solution was concentrated to ca. $5 \mathrm{~mL}$ and added to stirred diethyl ether (60 $\mathrm{mL}$ ) to produce the red precipitate $\mathbf{6 e}$, which was filtered and washed with diethyl ether. A solution of this red powder $\mathbf{6 e}(0.10$ g, $0.09 \mathrm{mmol})$ in $\mathrm{CH}_{2} \mathrm{Cl}_{2}(15 \mathrm{~mL})$ was heated to reflux for 6 days. Then the solution was concentrated to ca. $3 \mathrm{~mL}$ and added to diethyl ether $(40 \mathrm{~mL})$ to produce a red precipitate, which was filtered and washed with diethyl ether to give the product $7 \mathrm{e}(0.08 \mathrm{~g}, 82 \%$ yield $)$. Anal. Calcd for $\mathrm{C}_{65} \mathrm{H}_{57} \mathrm{~F}_{6} \mathrm{P}_{3} \mathrm{Ru}$ : C, 68.12; H, 5.01. Found: C, 67.91; $\mathrm{H}, 4.94 .{ }^{1} \mathrm{H}$ NMR $\left(\mathrm{CDCl}_{3}\right): \delta 7.89\left(\mathrm{~d}, 1 \mathrm{H},{ }^{3} J_{\mathrm{HH}}=7.6 \mathrm{~Hz}\right.$, anthracene), $7.42-6.77(\mathrm{~m}, 38 \mathrm{H}, \mathrm{Ph}), 5.86(\mathrm{~m}, 1 \mathrm{H},=\mathrm{CH}), 5.19$ $(\mathrm{s}, 5 \mathrm{H}, \mathrm{Cp}), 5.08\left(\mathrm{~d}, 1 \mathrm{H},{ }^{3} \mathrm{~J}_{\mathrm{HH}}=10.3 \mathrm{~Hz}\right.$, cis $\left.=\mathrm{CH}_{2}\right), 5.02(\mathrm{~d}, 1 \mathrm{H}$, ${ }^{3} J_{\mathrm{HH}}=17.3 \mathrm{~Hz}$, trans $\left.=\mathrm{CH}_{2}\right), 4.21($ br s, $1 \mathrm{H}, \mathrm{CH}), 2.76(\mathrm{~m}, 1 \mathrm{H}$, $\left.\mathrm{CH}_{2}\right), 2.44\left(\mathrm{~m}, 1 \mathrm{H}, \mathrm{CH}_{2}\right), 2.40\left(\mathrm{~m}, 1 \mathrm{H}, \mathrm{CH}_{2}\right), 2.32\left(\mathrm{~m}, 2 \mathrm{H}, \mathrm{CH}_{2}\right)$, $1.82(\mathrm{~m}, 1 \mathrm{H}, \mathrm{CH}), 1.74\left(\mathrm{t}, 1 \mathrm{H},{ }^{3} J_{\mathrm{HH}}=12.6 \mathrm{~Hz}, \mathrm{CH}\right), 1.58(\mathrm{~m}, 2 \mathrm{H}$, $\left.\mathrm{CH}_{2}\right), 0.96\left(\mathrm{~m}, 1 \mathrm{H}, \mathrm{CH}_{2}\right) .{ }^{13} \mathrm{C}$ NMR $\left(\mathrm{CDCl}_{3}\right): \delta 355.4\left(\mathrm{t},{ }^{2} J_{\mathrm{PC}}=\right.$ $\left.16.0 \mathrm{~Hz}, \mathrm{C}_{\alpha}\right), 137.7(=\mathrm{CH}), 145.6-120.4(\mathrm{Ph}$, anthracene $), 129.8$ $\left(\mathrm{C}_{\beta}\right), 115.5\left(=\mathrm{CH}_{2}\right), 90.7(\mathrm{Cp}), 58.7(\mathrm{C}($ bridgehead $)), 46.7\left(\mathrm{CH}_{2}\right)$, $45.3(\mathrm{CH}), 34.7\left(\mathrm{CH}_{2}\right), 32.7\left(\mathrm{CH}_{2}, \mathrm{CH}_{2}, \mathrm{CH}, \mathrm{CH}\right.$ (bridgehead)). ${ }^{31} \mathrm{P}$ $\mathrm{NMR}\left(\mathrm{CDCl}_{3}\right): \delta 43.52,39.45\left(2 \mathrm{~d},{ }^{2} J_{\mathrm{PP}}=26.7 \mathrm{~Hz}\right) . \mathrm{MS}: \mathrm{m} / \mathrm{z}$ $1001.3\left(\mathrm{M}^{+}\right)$.

Preparation of $\left\{[\mathrm{Ru}]=\mathrm{C}=\mathrm{CHCH}\left(9-\mathrm{Cl}-10-\mathrm{C}_{14} \mathrm{H}_{8}\right) \mathrm{CH}_{2} \mathrm{CH}_{2}\right.$ $\left.\mathbf{C H}=\mathbf{C H}_{2}\right\}\left[\mathbf{B F}_{4}\right](\mathbf{8})$. A dilute solution of $\mathrm{HBF}_{4} \cdot \mathrm{Et}_{2} \mathrm{O}$ in diethyl ether was added dropwise at $-20{ }^{\circ} \mathrm{C}$ to a stirred solution of $\mathbf{5 0}$ $(0.10 \mathrm{~g}, 0.10 \mathrm{mmol})$ in $20 \mathrm{~mL}$ of diethyl ether. Immediately, an insoluble solid precipitated but the addition was continued until no further solid was formed. The solution was then decanted, and the brown-green solid was washed with diethyl ether $(3 \times 5 \mathrm{~mL})$ and dried in vacuo to yield 8 ( $0.09 \mathrm{~g}, 84 \%$ yield $)$. Anal. Calcd for $\mathrm{C}_{62} \mathrm{H}_{52} \mathrm{BClF}_{4} \mathrm{P}_{2} \mathrm{Ru}$ : C, 68.80; H, 4.84. Found: C, 68.72; H, 4.88. ${ }^{1} \mathrm{H}$ NMR $\left(\mathrm{CDCl}_{3}\right): \delta 8.87\left(\mathrm{~d}, 1 \mathrm{H},{ }^{3} J_{\mathrm{HH}}=9.1 \mathrm{~Hz}\right.$, anthracene $), 8.72$ $\left(\mathrm{d}, 1 \mathrm{H},{ }^{3} J_{\mathrm{HH}}=9.2 \mathrm{~Hz}\right.$, anthracene), $8.61\left(\mathrm{~d}, 1 \mathrm{H},{ }^{3} J_{\mathrm{HH}}=9.1 \mathrm{~Hz}\right.$, anthracene), 7.74-6.62 (m, 35H, $\mathrm{Ph}$, anthracene), $5.82(\mathrm{~m}, 1 \mathrm{H}$, $=\mathrm{CH}), 5.48(\mathrm{~m}, 1 \mathrm{H}, \mathrm{CH}), 5.28\left(\mathrm{~m}, 1 \mathrm{H},=\mathrm{C}_{\beta} \mathrm{H}\right), 5.04\left(\mathrm{~d}, 1 \mathrm{H},{ }^{3} \mathrm{~J}_{\mathrm{HH}}\right.$ $=10.1 \mathrm{~Hz}$, cis $\left.=\mathrm{CH}_{2}\right), 4.99\left(\mathrm{~d}, 1 \mathrm{H},{ }^{3} \mathrm{~J}_{\mathrm{HH}}=17.8 \mathrm{~Hz}\right.$, trans $\left.=\mathrm{CH}_{2}\right)$, 4.49 (s, 5H, Cp), 2.26-2.16 (m, 3H, $\left.\mathrm{CH}_{2}, \mathrm{CH}_{2}\right), 1.93$ (m, $1 \mathrm{H}, \mathrm{CH}_{2}$ ). ${ }^{31} \mathrm{P}$ NMR $\left(\mathrm{CDCl}_{3}\right): \delta 43.71,39.77\left(2 \mathrm{~d},{ }^{2} J_{\mathrm{PP}}=26.7 \mathrm{~Hz}, \mathrm{PPh}_{3}\right)$. MS: $m / z, 995.5\left(\mathbf{M}^{+}\right)$.

Preparation of $\left\{\left[\mathrm{Ru}^{\prime}\right]=\mathrm{C}=\mathrm{C}(\mathrm{H}) \mathrm{CH}\left(9-\mathrm{Cl}-10-\mathrm{C}_{14} \mathrm{H}_{8}\right) \mathrm{CH}_{2}\right.$ $\left.\mathbf{C H}=\mathbf{C H}_{2}\right\}\left[\mathbf{P F}_{\mathbf{6}}\right]\left(\mathbf{8}^{\prime}\right)$. To a Schlenk flask charged with complex $\mathbf{3}^{\prime}$ $(0.10 \mathrm{~g}, 0.23 \mathrm{mmol})$ and $\mathrm{KPF}_{6}(0.13 \mathrm{~g}, 0.71 \mathrm{mmol})$ was added methanol $(10 \mathrm{~mL})$ under nitrogen. The resulting solution was stirred at room temperature, and $\mathbf{1 0}(0.08 \mathrm{~g}, 0.27 \mathrm{mmol})$ was added to the solution. In $4 \mathrm{~h}$ the color changed from yellow to orange. After the solvent was removed under vacuum, $30 \mathrm{~mL}$ of $\mathrm{CH}_{2} \mathrm{Cl}_{2}$ was added. The solution was filtered through Celite, and the volume of the solution was reduced to $5 \mathrm{~mL}$ under vacuum. Then $60 \mathrm{~mL}$ of ether was added to cause precipitation of orange powder. After filtration, the precipitate was washed with $10 \mathrm{~mL}$ of ether twice and then dried under vacuum to give the product $8^{\prime}(0.15 \mathrm{~g}, 78 \%$ yield $)$. Anal. Calcd for $\mathrm{C}_{37} \mathrm{H}_{50} \mathrm{ClF}_{6} \mathrm{P}_{3} \mathrm{Ru}: \mathrm{C}, 53.02 ; \mathrm{H}, 6.01$. Found: $\mathrm{C}$, 53.13; $\mathrm{H}, 6.17 .{ }^{1} \mathrm{H}$ NMR $\left(\mathrm{CD}_{3} \mathrm{COCD}_{3}\right): \delta 8.91-7.42(\mathrm{~m}, 8 \mathrm{H}$, anthracene), $\delta 5.19(\mathrm{~s}, 5 \mathrm{H}, \mathrm{Cp}), 5.69(\mathrm{~m}, 1 \mathrm{H},[\mathrm{Ru}]=\mathrm{C}=\mathrm{CH}), 5.80$ $\left(\mathrm{m}, 1 \mathrm{H}, \mathrm{CH}=\mathrm{CH}_{2}\right), 5.14\left(\mathrm{~d},{ }^{3} J_{\mathrm{HH}}=17.0 \mathrm{~Hz}, 1 \mathrm{H}\right.$, trans $\left.\mathrm{CH}=\mathrm{CH}\right)$, $5.05\left(\mathrm{~d},{ }^{3} \mathrm{~J}_{\mathrm{HH}}=9.4 \mathrm{~Hz}, 1 \mathrm{H}\right.$, cis $\left.\mathrm{CH}=\mathrm{CH}\right), 4.93(\mathrm{~m}, 1 \mathrm{H}, \mathrm{CH})$, $2.98-2.86\left(\mathrm{~m}, 2 \mathrm{H}, \mathrm{CH}_{2}\right), 1.89-1.38\left(\mathrm{~m}, 12 \mathrm{H}, \mathrm{CH}_{2}\right), 0.91-0.67$ $\left(\mathrm{m}, 18 \mathrm{H}, \mathrm{CH}_{3}\right) \cdot{ }^{13} \mathrm{C} \mathrm{NMR}\left(\mathrm{CDCl}_{3}\right): \delta 345.21\left(\mathrm{t},{ }^{2} J_{\mathrm{PP}}=15.1 \mathrm{~Hz}\right.$, $\left.\mathrm{C}_{\alpha}\right), 135.85-123.80$ (anthracene), $135.71\left(=\mathrm{CH}_{2}\right), 117.75(=\mathrm{CH})$, $116.68\left(\mathrm{C}_{\beta}\right), 89.54(\mathrm{Cp}), 41.36$ (C-anthracene), $31.52\left(\mathrm{CH}_{2}\right)$, 22.59-21.33 $\left(\mathrm{PCH}_{2}\right), 8.00-7.42\left(\mathrm{CH}_{3}\right) .{ }^{31} \mathrm{P} \mathrm{NMR}\left(\mathrm{CD}_{3} \mathrm{COCD}_{3}\right)$ : $\delta$ 38.41, $38.15\left(2 \mathrm{~d},{ }^{2} J_{\mathrm{PP}}=32.3 \mathrm{~Hz}, \mathrm{PEt}_{3}\right) . \mathrm{MS}: \mathrm{m} / z 693.6\left(\mathrm{M}^{+}\right)$.

Preparation of $\left\{[\mathrm{Ru}]=\mathrm{C}=\mathrm{CHCH}\left(\mathrm{C}_{14} \mathrm{H}_{9}\right) \mathrm{CH}_{2} \mathrm{CH}_{2} \mathrm{CH}=\mathrm{CH}_{2}\right\}$ $\left[\mathbf{B F}_{4}\right](\mathbf{8 e})$. A dilute solution of $\mathrm{HBF}_{4} \cdot \mathrm{Et}_{2} \mathrm{O}$ in diethyl ether was added dropwise at $-20{ }^{\circ} \mathrm{C}$ to a stirred solution of $\mathbf{5 e}(0.11 \mathrm{~g}, 0.11$ $\mathrm{mmol}$ ) in $20 \mathrm{~mL}$ of diethyl ether. Immediately, an insoluble solid precipitated, but the addition was continued until no further solid was formed. The solution was then decanted, and the brown solid was washed with diethyl ether $(3 \times 5 \mathrm{~mL})$ and dried in vacuo to yield $8 \mathrm{e}(0.10 \mathrm{~g}, 86 \%)$. Anal. Calcd for $\mathrm{C}_{62} \mathrm{H}_{53} \mathrm{BF}_{4} \mathrm{P}_{2} \mathrm{Ru}$ : C, 71.06; $\mathrm{H}, 5.10$. Found: C, 70.98; H, 5.12. ${ }^{1} \mathrm{H}$ NMR $\left(\mathrm{CDCl}_{3}\right): \delta 8.77(\mathrm{~d}$, $1 \mathrm{H},{ }^{3} J_{\mathrm{HH}}=9.3 \mathrm{~Hz}$, anthracene $), 8.50(\mathrm{~s}, 1 \mathrm{H}$, anthracene $), 8.11(\mathrm{~d}$, $1 \mathrm{H},{ }^{3} \mathrm{~J}_{\mathrm{HH}}=8.3 \mathrm{~Hz}$, anthracene $), 8.06\left(\mathrm{~d}, 1 \mathrm{H},{ }^{3} J_{\mathrm{HH}}=9.3 \mathrm{~Hz}\right.$, anthracene), $7.75\left(\mathrm{t}, 1 \mathrm{H},{ }^{3} J_{\mathrm{HH}}=7.2 \mathrm{~Hz}\right.$, anthracene), $7.57(\mathrm{t}, 1 \mathrm{H}$, ${ }^{3} J_{\mathrm{HH}}=7.1 \mathrm{~Hz}$, anthracene), 7.48-6.61 (m, 33H, Ph, anthracene), $5.79(\mathrm{~m}, 1 \mathrm{H},=\mathrm{CH}), 5.43(\mathrm{~m}, 1 \mathrm{H}, \mathrm{CH}), 5.23\left(\mathrm{~m}, 1 \mathrm{H},=\mathrm{C}_{\beta} \mathrm{H}\right), 4.99$ $\left(\mathrm{d}, 1 \mathrm{H},{ }^{3} J_{\mathrm{HH}}=9.3 \mathrm{~Hz}\right.$, cis $\left.=\mathrm{CH}_{2}\right), 5.12\left(\mathrm{~d}, 1 \mathrm{H},{ }^{3} J_{\mathrm{HH}}=20.3 \mathrm{~Hz}\right.$, cis $\left.=\mathrm{CH}_{2}\right), 4.34(\mathrm{~s}, 5 \mathrm{H}, \mathrm{Cp}), 2.18\left(\mathrm{~m}, 3 \mathrm{H}, \mathrm{CH}_{2}\right), 1.92\left(\mathrm{~m}, 1 \mathrm{H}, \mathrm{CH}_{2}\right)$. ${ }^{31} \mathrm{P} \mathrm{NMR}\left(\mathrm{CDCl}_{3}\right): \delta 44.06,39.27$ (two d, ${ }^{2} J_{\mathrm{PP}}=26.7 \mathrm{~Hz}, \mathrm{PPh}_{3}$ ). MS: $m / z, 961.1\left(\mathrm{M}^{+}\right)$.

X-ray Structure Determination of 7c. A single crystal of 7c suitable for an X-ray diffraction study was glued to a glass fiber and mounted on a Nonius Kappa CCD diffractometer. The diffraction data were collected using $3 \mathrm{~kW}$ sealed-tube molybdenum $\mathrm{K} \alpha$ radiation $(T=295 \mathrm{~K})$. The exposure time was $5 \mathrm{~s}$ per frame. Multiscan absorption correction was applied, and decay was negligible. Data were processed, and the structures were solved and refined by the SHELXTL program. ${ }^{15}$ The structure was solved using direct methods and confirmed by Patterson methods refining on intensities of all data to give R1 and wR2 for unique observed reflections $(I>2 \sigma(I))$. Hydrogen atoms were placed geometrically using the riding model with thermal parameters set to 1.2 times that for the atoms to which the hydrogen is attached and 1.5 times that for the methyl hydrogens. A solid-state structure determination was similarly carried out for $\mathbf{7 b}$. Table 1 gives parameters of the crystal data and refinement for complexes $\mathbf{7 c}$ and $\mathbf{7 b}$.

Acknowledgment. We thank the National Science Council for financial support.

Supporting Information Available: CIF files giving complete crystallographic data for $\mathbf{7 b}$ and $\mathbf{7 c}$. This material is available free of charge via the Internet at http://pubs.acs.org.

\section{OM8011294}

(15) SHELXTL: Structure Analysis Program, version 5.04; Siemens Industrial Automation Inc., Madison, WI, 1995. 